\title{
A Systematic Literature Review on the Participation Aspects of Environmental and Nature-Based Citizen Science Initiatives
}

\author{
Michalis A. Vasiliades ${ }^{1}\left(\mathbb{D}\right.$, Andreas Ch. Hadjichambis ${ }^{1,2, * \mathbb{D}}$, Demetra Paraskeva-Hadjichambi ${ }^{1,2}(\mathbb{D}$, \\ Anastasia Adamou ${ }^{1}$ (D) and Yiannis Georgiou ${ }^{1,2}$ (D) \\ 1 Cyprus Centre for Environmental Research and Education, Limassol 3304, Cyprus; \\ mv.kykpee@gmail.com (M.A.V.); d.hadjichambi@cytanet.com.cy (D.P.-H.); na.kykpee@gmail.com (A.A.); \\ yg.kykpee@gmail.com (Y.G.) \\ 2 Cyprus Ministry of Education, Culture, Sports and Youth, Nicosia 1434, Cyprus \\ * Correspondence: a.hadjichambis@cytanet.com.cy; Tel.: +357-99477309
}

\section{check for}

updates

Citation: Vasiliades, M.A.;

Hadjichambis, A.C.;

Paraskeva-Hadjichambi, D.; Adamou,

A.; Georgiou, Y. A Systematic

Literature Review on the

Participation Aspects of

Environmental and Nature-Based

Citizen Science Initiatives.

Sustainability 2021, 13, 7457.

https://doi.org/10.3390/su13137457

Academic Editor: Corrado Battisti

Received: 19 May 2021

Accepted: 29 June 2021

Published: 3 July 2021

Publisher's Note: MDPI stays neutra with regard to jurisdictional claims in published maps and institutional affiliations.

Copyright: (C) 2021 by the authors. Licensee MDPI, Basel, Switzerland. This article is an open access article distributed under the terms and conditions of the Creative Commons Attribution (CC BY) license (https:// creativecommons.org/licenses/by/ $4.0 /)$
Abstract: It is commonly argued that, despite the tremendous resonance Citizen Science (CS) has shown in recent years, there is still lack of understanding of important aspects defining citizens' participation and engagement in CS initiatives. While CS initiatives could provide a vehicle to foster forms of participation contributing to the democratization of science, there is still limited attention paid to the "Citizen" component of the Citizen Science term. For the purpose of this work, we systematically reviewed the available literature for empirical studies in respect to citizens' participation in environmental and nature-based CS initiatives established during the last two decades, using the PRISMA methodology. The participatory facet of the retrieved 119 CS initiatives was analysed on the basis of: (a) exclusion and inclusion demographic factors, (b) CS models and practices, (c) facilitators and constraints of citizen's participation, and (d) environmental citizenship. Our findings show that the majority of the CS initiatives did not place restrictions on gender participation; however, we have identified that mostly highly educated adults participated in the reviewed initiatives. In addition, most of the CS initiatives reported in the literature were situated in the EU and USA, were mostly limited to the local scale, and primarily followed the contributory model. Academic institutions were found to coordinate the majority of the CS initiatives examined. By using digital technologies, academic scientists were able to control and increase data quality, as well as to engage a broader audience, even though they were mostly treating volunteers as "data collectors", desiring their long-term engagement. Therefore, it will be of CS benefit to be better aligned with the mentality and needs of citizens. In this direction CS initiatives should trigger citizens' learning gains and interpersonal/social benefits and personal, environmental, and social motivations, but also to shift their goals towards contributing to science and citizens' connection with nature. On the other hand, there is a need to overcome any design and implementation barriers, and to enhance democratization through a more participative engagement of active and aware citizens, thus promoting environmental citizenship.

Keywords: nature-based citizen science; environmental citizen science; participation; inclusion; exclusion; facilitators; constraints; models and practices; environmental citizenship; systematic literature review

\section{Introduction}

Public participation in scientific research has a long history, with the use of non-experts as the primary source of collection of large amount of data on behalf of professional scientists [1,2]. Nowadays, the term Citizen Science (CS) describes the involvement, engagement, and communication of the public (e.g., volunteers, students or activists) with professional scientists, in collecting data and gathering information in various fields of science, such as nature, ecology, and the environment [3-7]. The interaction between the public and scientists can be seen as an amphidromic procedure promoting public participation in science, where among other things the former gain knowledge and skills throughout data 
collection and the latter use these large-scale data, that may not be easily gathered with other techniques, for the common good, thus resulting in a win-win situation $[8,9]$.

Despite the long history of CS, there are still several limitations in the underlying models and frameworks, which guide the public participation in CS initiatives. In many CS initiatives, the citizens are merely treated as "data collectors" or "passive" participants [10], instead of "active citizens" [11]. This finding is not surprising, given that CS research is not focused, for instance, on how CS can help the public to understand and appreciate the power of science for socio-political and socio-cultural action [6]. However, CS can be an excellent venue for the democratization of science, by achieving an "inclusive" and active engagement of citizens in the scientific process.

As CS has blossomed in recent years, many professional networks have been founded around the globe (e.g., International, European, US-based and Australian Citizen Science Association), aiming to advance the proper design of methodologies for the effective implementation of nature-based and environmental CS initiatives. In addition, these associations aim at addressing any inaccuracies for who is counted as "scientist" and who as "citizen", while also attempting to connect more effectively citizens with nature, as well as ensuring the appropriate use of citizens' data towards decision- and policy-making, for a more sustainable environment $[12,13]$.

Aligned with the aforementioned concerns and remedial actions, this study presents a systematic review of the available empirical research on citizens' participation in environmental and nature-based CS. More specifically, the participatory aspects of a total of 119 CS initiatives were analysed on the basis of: (a) exclusion and inclusion demographic factors, (b) CS models and practices defining citizens' participation, (b) facilitators and constraints of citizen's participation, and (d) participation forms for the achievement of environmental citizenship. The rest of the manuscript continues with (i) providing an overview of environmental and nature-based CS initiatives, (ii) defining the participatory aspects of CS initiatives, and (iii) reflecting on how CS initiatives can serve as a venue to foster Environmental Citizenship. This theoretical background motivates the research questions guiding this review effort, which will be presented in the following sections.

\subsection{Overview of Environmental and Nature-Based CS Initiatives}

When the term "citizen science" was coined in the 19th century it was not well defined, but there are many examples of environmental and nature-based CS initiatives, which were carried out by volunteers without professional training in science [14]. In recent years, environmental and nature-based CS initiatives mainly deal with public monitoring for data collection from trained non-specialist citizens, aiming to address various environmental problems as well as to contribute to nature conservation. These include but are not limited to CS initiatives related to air pollution (e.g., Air Sensor Toolbox, Smoke Sense), bird monitoring (e.g., Galaxy Zoo (http:/ / www.galaxyzoo.org/, accessed on 28 June 2021), eBird (http:/ / www.ebird.org/, accessed on 28 June 2021), NestWatch (https:/ / nestwatch.org/, accessed on 28 June 2021), FeederWatch (https: / feederwatch.org/, accessed on 28 June 2021), Big Butterfly Count (https:/ / bigbutterflycount.butterfly-conservation.org/, accessed on 28 June 2021), biodiversity conservation (e.g., GBIF (https: / /www.gbif.org/, accessed on 28 June 2021)), and water quality (e.g., bloomWatch (https:/ / cyanos.org/bloomwatch/, accessed on 28 June 2021)) [15]. For instance, bird monitoring and butterflies' observation by volunteers are considered among the oldest nature-based CS initiatives [16,17]. In fact, during the last few decades there has been an increasing emphasis on CS initiatives focusing on: (i) improving citizens' understanding on ecology and nature by providing place-based experiences, (ii) developing citizens' scientific practices and scientific knowledge, and (iii) promoting conservation actions with reflect on policy- and decision-making [3,8].

Framing CS initiatives involves several risks due to the various differences attributed to the different fields explored, and the different methodological approaches followed in relation to the development, implementation, and evaluation of each initiative [8]. Various research groups have already attempted to understand CS models and practices regarding 
citizens' engagement $[14,18-20]$. However, the derived outcomes should be carefully correlated with all the inclusive and exclusive factors affecting citizens' participation.

\subsection{Participation Aspects of CS Initiatives}

Citizens' participation in CS initiatives has been raised by various research groups in the literature, underlying the importance of several participation aspects for those involved (e.g., social, individual, civic, civil participation, etc.), from different perspectives and angles $[2,5,18,21-23]$. However, there is a limited number of CS initiatives focusing on the promotion of an inclusive participation which can ideally lead science towards democratization [24]. Considering the classification of Shirk et al. (2012), and the attempts to address socio-cultural and socio-political theoretical frames within CS initiatives, different degrees of public participation have been identified so far, classifying the levels of citizens' involvement into "contractual", "contributory", "collaborative", "co-created", and "collegial". In contractual CS initiatives, the scientists conduct, for instance, an investigation requested by the communities. On the other hand, contributory and collaborative CS initiatives are designed by scientists; however, in the former case, citizens take part as "data collectors", while in the latter case the citizens also contribute to the design, data analysis, and/or dissemination of the outcomes. Co-created initiatives are co-designed by both scientists and citizens, and they are characterised by the active participation of citizens throughout the whole duration of the project. Collegial initiatives are the ones where citizens conduct an investigation independently, while expecting recognition from scientists. Despite the significance of designing collaborative and co-created initiatives, in which citizens are actively engaged, there are many CS initiatives which use contributory approaches, where citizens are simply taking the role of "passive sensors" providing the required data to the scientists $[11,25,26]$.

It is also of paramount importance to mention that there are also some factors known as "facilitators", which may increase the interest of citizens in participation, and conversely factors known as "barriers", which may prohibit citizens' participation in CS initiatives. In a CS initiative that took place in Rwanda, as an attempt to control malaria under the Environmental Virtual Observatories for Connective Action (EVOGA) multidisciplinary project, the authors reported that the engagement of citizens along the continuation of the project was facilitated by the ease of using observational materials (i.e., in-depth interviews, mobile phones, workshop) on their reports, but also from the fact that the participants were feeling useful to the program, as their efforts were well recognized by the scientists and the community [27]. On the other hand, in a hypothetical Australian marine CS initiative, it was revealed that a major barrier for citizens to participate in the initiative was their insufficient knowledge of marine species, which made it difficult for them to contribute effectively [28]. Stakeholders (e.g., scientists, community actors, NGOs, etc.) in CS initiatives should better understand citizens' benefits, motivations, goals, and constraints, along with the use of best practices incipient from the design and implementation of their initiatives [18,29-34]. Therefore, it becomes imperative to systematically examine the facilitators and barriers, which may affect positively or negatively, respectively, citizens' participation in CS initiatives [35].

The development of digital technologies has also contributed to the growth of CS, providing an easily accessible source of communication with and among participants, from data collection towards the analysis, interpretation, and dissemination of outcomes to a broader audience [36]. Digital technologies have increased the visibility of CS initiatives and given opportunities to unidentified and underrepresented groups to participate and contribute to science [37]. However, the use of digital technologies carries risks as it: (i) focuses primarily on the data collection aspects of the CS initiatives, and (ii) creates population imbalance due to the digital divide, excluding those who do not advanced ICT (Information Communication Technology) knowledge or the infrastructure needed [38,39].

Besides that, it is crucial to identify how CS initiatives are designed, managed, and implemented (i.e., existing CS models and practices) with respect to citizens' participa- 
tion as well as the approaches used to eliminate any inclusive or exclusive demographic factors, such as gender, age, and education [40-42]. As reported in the literature, there are several discrepancies due to the impact of demographic factors, which deter citizens from participating in CS initiatives $[29,43]$. Thus, the necessity to carefully and thoroughly design and manage CS initiatives to unrestrictedly engage citizens beyond the collection and submission of data, is imperative [18,29-34]. Therefore, there is a need now more than ever to focus on the active involvement of citizens and promote environmental citizenship, where citizens will be benefited and motivated via their contribution to science and nature conservation [44].

\subsection{Participation in CS Initiatives as a Venue to Cultivate Environmental Citizenship}

Existing models and practices of CS initiatives, place the emphasis on the "science" rather than on the "citizen" component [44]. However, when it comes to CS initiatives, it is also of paramount importance to give the necessary emphasis to the "citizen" component in the "Citizen Science" term $[23,45]$. This change will also shift the focus of CS initiatives from citizens as "data collectors" to citizens as "active participants". In turn, this will also contribute to the empowerment of citizens' knowledge, values, attitudes, skills, competences, and behaviours in order to promote their ability to undertake socio-environmental and environmental citizenship actions [46-48]. Environmental citizenship is defined as a multifaceted concept, which deals with pro-environmental behaviour and citizens' attitudes towards the environment. According to the recent definition given by the European Network for Environmental Citizenship (ENEC, 2018):

"Environmental Citizenship is defined as the responsible pro-environmental behaviour of citizens who act and participate in society as agents of change in the private and public sphere on a local, national and global scale, through individual and collective actions in the direction of solving contemporary environmental problems, preventing the creation of new environmental problems, achieving sustainability and developing a healthy relationship with nature. Environmental Citizenship includes the practise of environmental rights and duties, as well as the identification of the underlying structural causes of environmental degradation and environmental problems and the development of the willingness and the competences for critical and active engagement and civic participation to address those structural causes and to act individually and collectively within democratic means, taking into account inter-and intra-generational justice."

Within this context, an emerging question is whether CS initiatives, and especially environmental and nature-based ones, can endorse forms of participation which can support and promote environmental citizenship. In their review study, Wiggins and Crowston [20] constructed a matrix of CS typologies, after examining 30 CS initiatives in relation to the nature of citizens' participation. Therein, the reviewed CS initiatives were clustered into five mutually exclusive and exhaustive types of initiatives including action (2 CS initiatives out of 30), conservation (7 out of 30), investigation (10 out of 30), virtual (7 out of 30), and education (4 out of 30). By definition, action-related CS initiatives are using bottom-up approaches (scientific research) to encourage participant intervention in local concerns and support civic agendas. Therefore, action-related CS initiatives could potentially contribute to the cultivation of environmental citizenship and enhance the engagement of participants through encouragement as a way to address socio-political and socio-cultural issues. In addition, such CS initiatives could potentially promote citizens ${ }^{\prime}$ active participation as a venue to address large-scale environmental issues, prevent new ones, as well as to achieve sustainability and a healthy relationship with nature [49-51].

\subsection{Study Overview and Research Questions}

The present review study aims into systematically examine the participation aspects of nature-based and environmental CS initiatives by following the PRISMA methodology [52]. In particular, our aim was four-fold and it is reflected in the following research questions (RQs): 
- RQ1: Which are the main exclusion and inclusion demographic factors, defining citizens' participation in nature-based and environmental CS initiatives?

- RQ2: How do existing CS models and practices define citizens' participation in naturebased and environmental CS initiatives?

- RQ3: Which are the main facilitators and constraints of citizen's participation in nature-based and environmental CS initiatives?

- RQ4: Do nature-based and environmental CS initiatives provide a participation venue that fosters environmental citizenship?

\section{Methodology}

\subsection{Data Collection}

The studies analysed in this literature review covered empirical research published within 2000 to 2020, in English language, as a full paper in a peer-reviewed academic journal. The retrieval of the reviewed studies followed the PRISMA standards for Systematic Literature Reviews [52] and was based on a multi-step procedure comprised of three sequential stages, as follows: (a) Identification, (b) Screening, and (c) Eligibility (Figure 1).

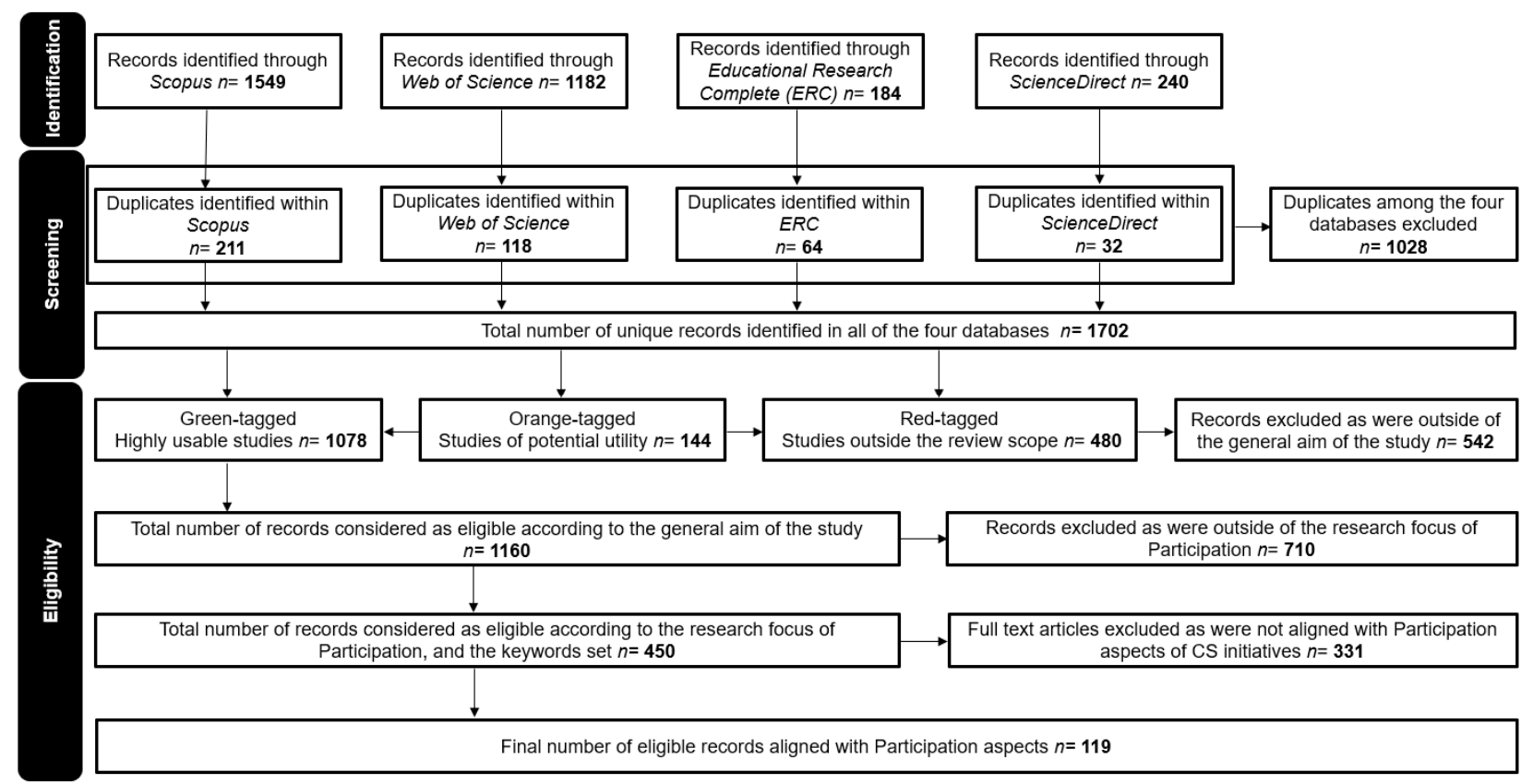

Figure 1. Flow diagram illustrating the review selection process.

Initially, at the identification step, the published literature was surveyed using four electronic databases: Scopus, Web of Science, Education Research Complete (via EBSCO), and ScienceDirect, which are considered among the most enriched and popular academic databases [53]. The keywords checked on the title/abstract/keywords included the terms "citizen science", "open science", "public science", "participatory science", "civic science", and "community science" in combination with the terms "nature", "ecology", and "environment" (e.g., "citizen science" AND "environment", "civic science" AND "nature"), leading to 18 combinations. This ensured that the retrieved results would be mostly restricted in the context of nature-, ecology-, and environment-related CS initiatives. After performing all possible combinations, a total of 3155 papers were retrieved.

For the second step (screening), these records were screened and both internal duplicates within each database, and duplicates between the four databases were removed, resulting in a total of 1702 records.

For the third step (eligibility), the remaining records were filtered, to identify their eligibility, according to their Research scope; the study should report on the design, implementation, and/or management of at least one nature or environmental-based CS initiative. 
Getting more in-depth, as part of this process the title/abstract/keywords of studies were evaluated using the following color coding: (a) Green-tagging, for highly usable studies aligned with the criteria posed, (b) Red-tagging for studies outside the review scope, not aligned with the criteria posed, and (c) Orange-tagging for studies of potential utility, given that these studies seemed quite relevant to the scope of this review, but it was not absolutely clear whether all the inclusion criteria were met. In this latter case, full text versions of the studies were also obtained, read, and colored as green or red. Overall, the first part of this eligibility procedure resulted in the selection of 1160 green-tagged studies. The selected publications were further evaluated according to their research focus and research methods. More specifically, a filtering was performed to ensure that the CS initiatives were explicitly related to the aspects of participation (research focus), as these were outlined in the introduction of the study. For this filtering, a second group of 10 relevant keywords was deployed to search within the title/abstract/keywords of the retained papers, as follows: "participation", "engagement", "involvement", "inclusion", "benefit", "goal”, “barrier", "motive", "motivation", and "obstacle". This filtering process resulted into 450 journal articles.

Finally, the filtering process was concluded with the thorough study of the 450 articles, and their separation based on their research methods into: (i) empirical papers, reporting on one CS initiative with a focus on participation, and providing primary data derived from quantitative, qualitative, or mixed designs, (ii) review papers, and (iii) theoreti$\mathrm{cal} /$ conceptual papers, which did not include any empirical data. This latter filtering led to exclusion of any theoretical/conceptual and review papers lacking any empirical data. Therefore, we concluded with one hundred and nineteen empirical articles $(N=119)$, hence 119 CS initiatives, which were fully analysed in order to extract all relevant information related to the research questions posed.

\subsection{Data Analysis}

The 119 retrieved empirical studies were analyzed by using a semi-structured checklist including a matrix of CS participation-related typologies, aligned with the four research questions guiding this study.

The first matrix of typologies consisted of various exclusion and inclusion demographic factors, aimed to capture relevant information for the demographic make-up of participants in the reviewed CS initiatives (e.g., gender, age, educational level). In addition, this matrix of typologies also included general demographic characteristics in relation to CS initiatives, such as the geographical scale and region of each CS initiative, as well as the initiatives coordinator.

The second matrix of typologies was related to the CS models and practices which may define and affect citizens' participation. Relevant information such as the overarching aims of the CS initiatives as well as their goals in relation to science learning [54] were captured. This matrix of typologies also included information related to the data collection process (e.g., level and modes of data collection, frequency, and duration of data collection) as well as the forms, activities, and types of citizens' contributions in CS initiatives. In addition, typologies addressing the modes and topics of communication with and among participants in CS initiatives were included.

The third matrix of typologies was related to the facilitators and constraints of citizen's participation in CS initiatives. With this matrix we aimed at collecting relevant information regarding the factors which may act as facilitators for participation in CS initiatives such as the citizens' benefits and motives, as well as the citizens' goals guiding their active involvement in CS initiatives. On the other hand, with this matrix we also aimed at collecting relevant information regarding the factors which may act as barriers for citizens' participation in CS initiatives.

The fourth matrix of typologies was related to environmental citizenship, as it aimed to capture information regarding the potentials of current CS initiatives to support forms of participation fostering environmental citizenship. More specifically, with this matrix 
we aimed at collecting information regarding the dimensions (individual and collective) spheres (private and public), and scales (local, national, global) of the actions promoted by the CS initiatives towards environmental citizenship, but also regarding the outcomes of environmental citizenship.

Further data analysis was performed over the retrieved results to shed light on the participation-related aspects of the CS initiatives, falling into the four aforementioned matrix of typologies. Specifically, for each typology, the Relative Frequency (RF, \%) was estimated by using the following Equation (1) [55]:

$$
\text { Relative Frequency }(\%)=(A / B) \times 100
$$

where $\mathrm{A}$ is equal to the exact number of appearances of a specific option of each typology (known as absolute frequency), and B is equal to the total number of appearances of all the options of each typology (N). For instance, for the initiatives' coordinator typology in CS initiatives (see the first matrix of typologies), the option "Academic institution" was found in 33 articles. Considering that "NGO" (11 articles), and "Governmental organization" (8 article) options were also observed, the number $(\mathrm{N})$ of appearances of the initiatives' coordinator typology was raised to 52. Thus, the relative frequency of Academic institution within the initiatives' coordinator typology, estimated via Equation (1), is $R F(\%)=(33 / 52)$ $\times 100=63 \%$. All the percentages from now on in this paper use the above-mentioned relative frequency to draw a clear picture on how each typology was reflected in the reviewed studies, without weighting on who proposes the statements coded, or how many participants there were. In addition, the total number of appearances $(\mathrm{N})$ for each typology is reported in figures' captions. It is noteworthy to mention at this point that the whole procedure was screened and confirmed by two reviewers of the current study. To increase inter-rater reliability, any differences among the two reviewers were further discussed and resolved by all five authors.

\section{Results}

\subsection{Exclusion and Inclusion Demographic Factors}

Demographic data can be treated as descriptive statistics of the participants in the reviewed CS initiatives. However, at the same time, demographic data can provide a valuable resource of important information regarding the inclusion/exclusion factors affecting public participation in a CS initiative. As it can be seen in Figure $2 a$, most of the participants were adults (71\%); however, $29 \%$ of CS initiatives were using participants under the age of 18 (U18). In line with our findings, as also reported during the evaluation of a long-term CS initiative which took place in Northern Spain (MONITO) " ... ages range between 23 and 77 years old" [56] (p. 394). As shown in Figure 2b, there were no issues preventing participants from contributing to a CS initiative due to their gender, as both males and females were found to participate in the vast majority (97\%) of CS initiatives. For example, a questionnaire developed to retrieve information regarding the motivations and scientific attitudes from past participants of the Manitoba Nocturnal Owl Survey revealed that "Respondents were fairly evenly split by gender" [57] (para. 15). The educational level of citizens participating in CS initiatives (see Figure 2c) seems to clearly illustrate that most of the participants had, at least, high school diploma (22\%) and were educated with a bachelor's degree (21\%). Nevertheless, there is also a measurable number of postgraduate MSc or PhD holders (27\%), as opposed to middle school and primary education participants $(17 \%)$. The latter trend is in line with the results presented in Figure 2a regarding the age of citizens participating in a CS initiative. In other words, based on our results, $61 \%$ of the participants, were at least college degree holders. In line with our findings, the Great Pollinator CS initiative which was based on survey outcomes, reported that "More than three quarters had obtained a college degree" [58] (p. 42). Additionally, based on demographic information from the Smoke Sense CS initiative, it is specifically mentioned that "Participants of Smoke Sense during the pilot study were younger $(30.2 \%$ age 
18-29; $25 \%$ age $30-39 ; 19.3 \%$ age $40-49 ; 18.9 \%$ age $50-64$; and $6.5 \%$ age $65+)$, more educated (71.6\% had at least a college degree)" [59] (p. 447).

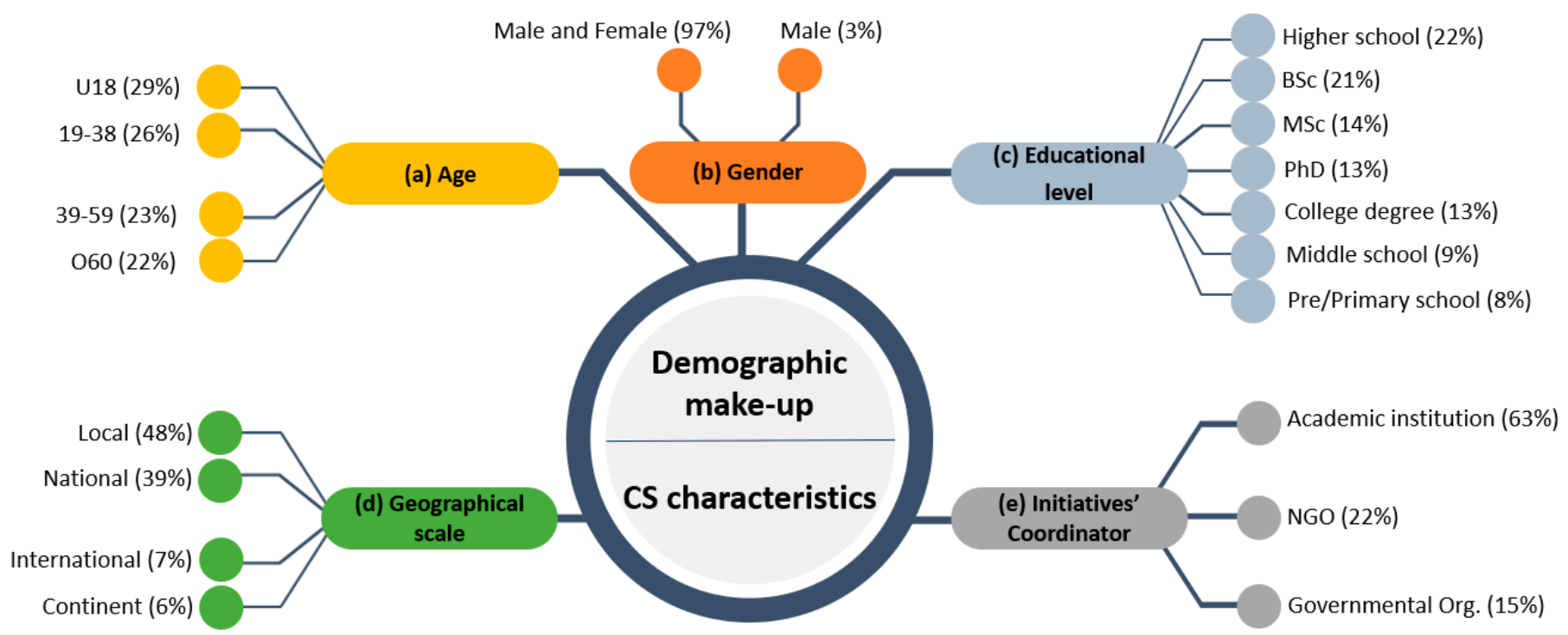

Figure 2. (a) Gender $(\mathrm{N}=37)$, (b) Age $(\mathrm{N}=26)$, (c) Educational level $(\mathrm{N}=33)$ of citizens, (d) Geographical scale $(\mathrm{N}=95)$, and (e) Coordinator $(\mathrm{N}=52)$ in CS initiatives.

Figure 2d,e and Figure 3 present additional general demographic characteristics of CS initiatives, in terms of the geographical scale, the region, and the initiatives' coordinator. As shown in Figure 2d, most of the CS initiatives reported in the available literature, were locally oriented (48\%), with a measurable quantity taking also place at national level (39\%). On the other hand, only a few studies were expanded more broadly on the continental and international level (6 and 7\%, respectively). "Involving local communities in conservation initiatives increases a community's appreciation", as clearly shown in an article exploited during our literature review, related to a case study from the DeHoop Nature Preserve in South Africa [60] (p. 1196). The coordination of CS initiatives was mostly (63\%) undertaken by academic institutions (Figure 2e). However, $37 \%$ of the CS initiatives, were also found to be coordinated either from a non-governmental (NGO) or a governmental organisation.

American and European countries seemed to have a more leading role in CS initiatives (38 and 36\%, respectively), opposed to the Oceanian (15\%), African (6\%), and Asian $(5 \%)$ ones (see Figure 3). It is worth mentioning that CS initiatives identified in Russian Federation, were situated in the European part of it (as far as the Ural mountains imaginary line separation), rather than the Northern Asia part. However, for uniformity purposes, all Russian Federation is shown within Europe. Similar trends were also observed in The School of Ants Project, where the authors explicitly state that "Most visits were from people in the United States (84.9\%)." [61] (p. 4). 


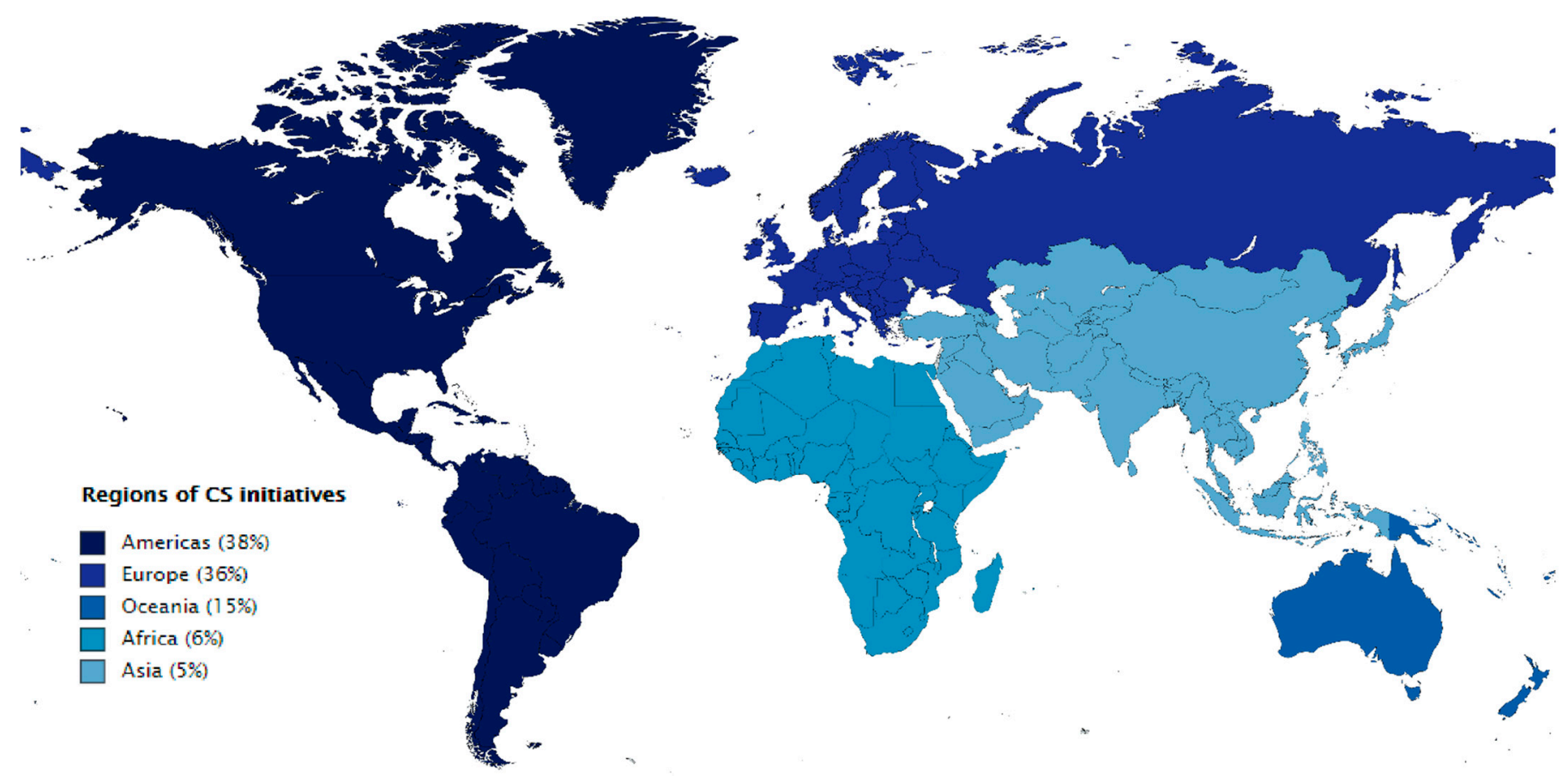

Figure 3. Region $(\mathrm{N}=85)$ of $\mathrm{CS}$ initiatives.

\subsection{CS Models and Practices}

In order to study the components of CS models and practices in relation to public participation, we initially analyzed the available information regarding the overarching aims of the reviewed CS initiatives, as well as their science learning related goals (see Figure 4). It can be clearly seen that "nature conservation" and "awareness" were among the prioritized overarching aims of CS initiatives ( $20 \%$ each category), with "education" and "environmental management" to closely follow (16 and 14\%, respectively). In contrast, $30 \%$ of CS initiatives reported that their overarching aim was to contribute to "social and economic research", and to provide data towards "actions" or "improving methods".

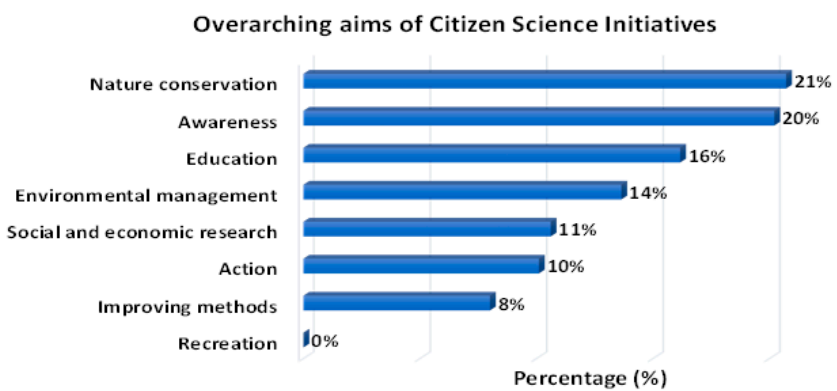

(a)

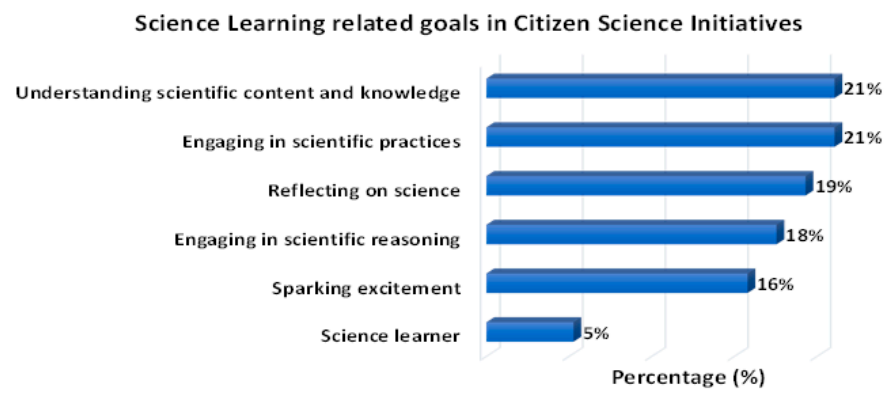

(b)

Figure 4. (a) Overarching aims of CS initiatives $(\mathrm{N}=73)$, and $(\mathbf{b})$ Science learning related goals in CS initiatives $(\mathrm{N}=26)$.

The studies identified in the literature referring to science learning related goals were limited $(\mathrm{N}=26)$. In particular, as it can be seen in Figure $4 \mathrm{~b}$, "understanding of scientific content and knowledge", and "engaging in scientific practices", were the main science related learning goals of CS initiatives (21\% each category) followed by "reflecting on science" (19\%), "engaging in scientific reasoning" (18\%), and "sparking excitement towards science learning". For instance, in a very recent publication reviewed in our study, regarding a contributory CS initiative named Helsinki Urban Rat Project, the following statement is remarkable: "The students described multiple ways that participation led to an 
increase in their interest and resulted in diverse learning outcomes ... as a way of increasing personal interest in science" [62] (p. 333).

Our review also highlights the data collection processes within the CS initiatives focusing on the level, frequency, and duration of the data collection process outlined in each CS initiative. In addition, we aimed into identifying the modes of engagement and for how long citizens were engaged in CS initiatives.

Specifically, as illustrated in Figure 5a, the majority (58\%) of the CS initiatives involved a single person as the data collector. Additionally, there was also a plethora of CS initiatives using small groups of citizens (33\%). On the other hand, only a limited number of CS initiatives preferred pairs of citizens $(8 \%)$, with almost zero initiatives to pursue entire communities as data collectors (1\%). One of the major forms of citizens' participation, with reports in more than $87 \%$ of CS initiatives, is that of volunteering (see Figure $5 b$ ), as individuals had the chance to join, retain, or leave a project at any time without any consequences. However, there was also a small number of CS initiatives (11\%) supporting citizens' participation through compensation, which was at least preferable to the pay-toparticipate (2\%) form of citizens' contribution. Additionally, $74 \%$ of CS initiatives reported that citizens were reporting multiple entries over an extended time period (Figure $5 \mathrm{c}$ ), as opposed to the one-time only reports (26\%). Regarding the modes of engagement shown in Figure 5e, $80 \%$ of CS initiatives reported that citizens were engaged only with data rather than actively engaged $(20 \%)$ by putting personal physical or intellectual effort. As shown in Figure 5f, participants in $70 \%$ of CS initiatives were contributing, for the purposes of the project, from 1-10 h in total (minimum duration), however some initiatives (22\%) required maximum duration $(>24 \mathrm{~h}$ ) and few of them ( $8 \%$ ) reported that the contribution from citizens was in the range of 11-24 $\mathrm{h}$ (medium duration). On a recent publication for the evaluation of CrowdHydrology CS project, included in our review, it was stated that "One-time participants are helpful and may be all that are needed in the case of monitoring a specific event in real-time. However, for developing historical trends at a site for monitoring long-term change, requires transitioning one-time participants into champions." [63] (p. 6).

Another important finding from our literature review relates to the citizens' activities, and types of citizens' contributions in CS initiatives. Conducting and monitoring observation along with the collection and submission of data were the primary citizens' activities ( $\sim 35 \%$ each category), reported in the reviewed CS initiatives (see Figure $5 \mathrm{~g}$ ). However, a limited number of CS initiatives indicated that citizens' activities were also related to the receiving of training $(14 \%)$. It is noteworthy that only few CS initiatives reported citizens' activities related to the advice on the analysis or the design of the study or protocol $(<5 \%)$. The latter results are also in very good agreement with the types of citizen contributions in CS initiatives, as presented in Figure $5 \mathrm{~d}$, as the majority of the reviewed initiatives tended to include contributory $(46 \%)$ and contractual $(36 \%)$ involvement from citizens, rather than collaborative, collegial, or co-created type of contribution $(<20 \%)$.

Figure 6 illustrates the internal and external communication with and among participants. The modes of communication, as shown in Figure 6a, were primarily performed via web-based platforms (40\%), and to a lesser extent through in-person meetings (17\%). However, some CS initiatives preferentially chose the use of written information, social media, graphical display, telephone, and regular newsletter, as the way of communication with and among participants. The topics which participants were communicating with each other included mostly the initiative's data (31\%), or aspects related to training and recruiting (21 and 15\%, respectively), rather than the discussion of results, actions, or socializing between them (see Figure 6b). For example, as reported for the purposes of the Great Pollinator Project, in a recent article exploited during our review, "Throughout the season, project coordinators stayed in touch with volunteers via email and blog posts to encourage data submission and highlight seasonal observations" [58] (p. 41). It is important to note that most of the CS initiatives were using digital technologies as the primary source of communication, either for controlling data quality or improving data collection, or as a way to motivate volunteers and engage broad audiences. 
(a) Level of data collection (b) Forms of citizens'

- Single person (58\%) participation

- Small group of citizens (33\%)

- Pair of citizens (8\%)

- Entire community (1\%) (c) Frequency \& Duration of participation

- Multiple times over an extended period (74\%)

- One-time (26\%) (d) Types of citizens' contribution

- Contributory (46\%)

- Contractual (36\%)

- Collaborative (18\%)

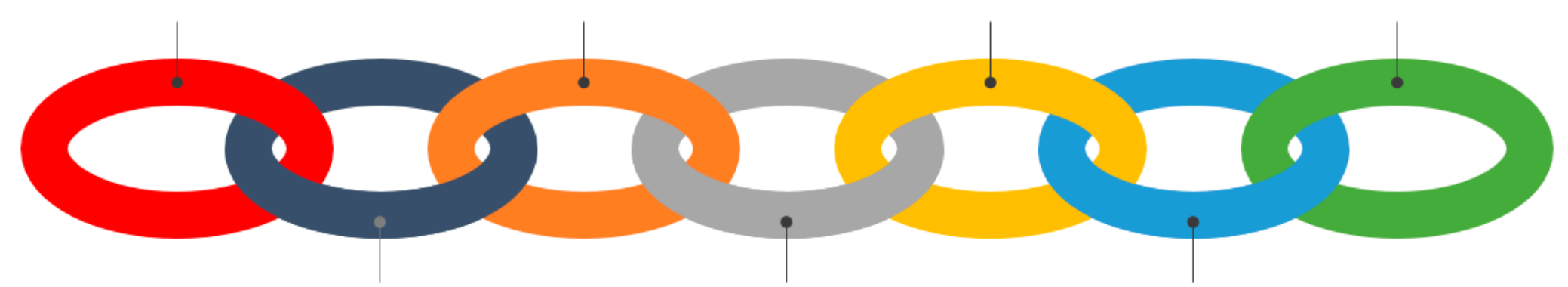

(e) Modes of engagement

- Engaged only with data (80\%)

- Actively engaged (20\%) (f) Duration of engagement

- Minimum duration (70\%)

- Maximum duration (22\%)

- Medium duration (8\%)

\section{(g) Activities citizens involved}

- Conducting and monitoring observations (37\%)

- Collecting and submitting data (35\%)

- Receiving training (14\%)

- Advising on analysis (4\%)

- Designing study or protocol (3\%)

- Using data as evidence in decision making (2\%)

- Drawing conclusions and desiminating results $(2 \%)$

- Defining the problem, issue or question (1\%)

- Asking new questions and taking actions (1\%)

- Developing research hypothesis (1\%)

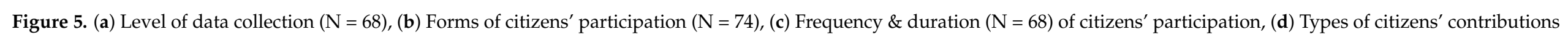
$(\mathrm{N}=65)$, (e) Modes of engagement $(\mathrm{N}=57)$, (f) Duration of engagement $(\mathrm{N}=50)$, and (g) Citizens' activities $(\mathrm{N}=63)$ in $C S$ initiatives. 


\section{Modes of communication in Citizen Science Initiatives}

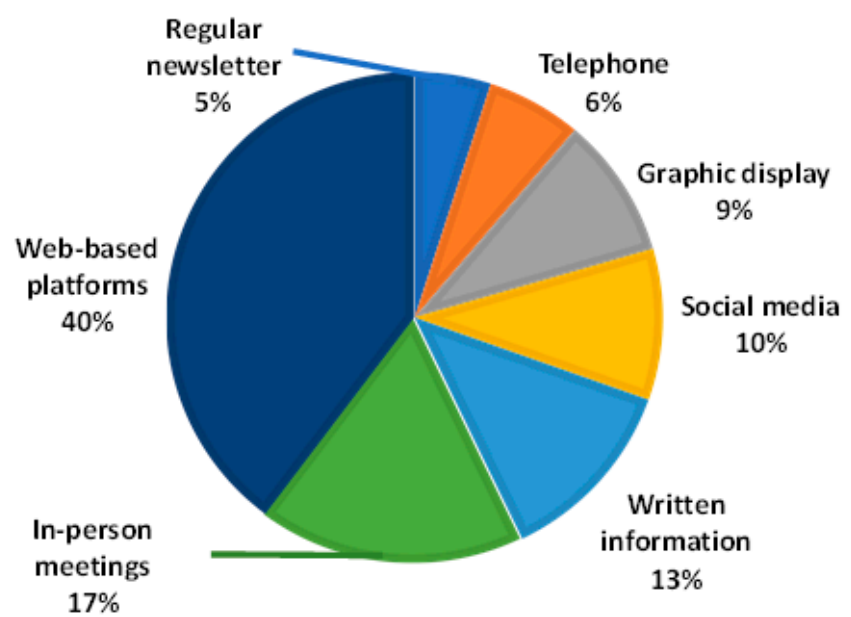

(a)

\section{Topics of communication in} Citizen Science Initiatives

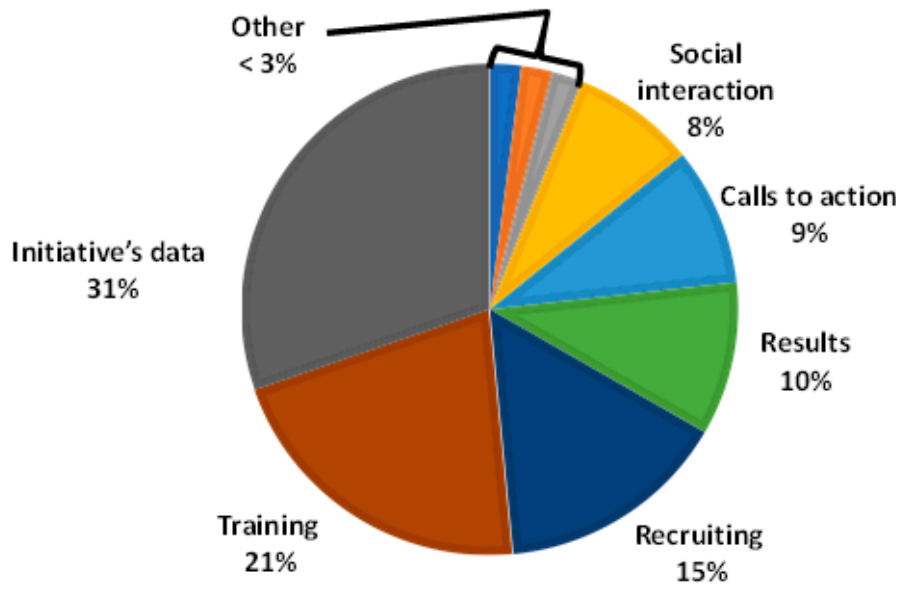

(b)

Figure 6. (a) Modes of communication $(\mathrm{N}=75)$, and $(\mathbf{b})$ Topics of communication $(\mathrm{N}=88)$ of participants in $\mathrm{CS}$ initiatives.

\subsection{Facilitators and Constraints of Citizens' Participation}

Concrete results revealed trends on important aspects defining citizens' participation in CS initiatives, related to various facilitators (e.g., citizens' goals, benefits, motivations), and constraints (e.g., extensive time requirements, limited funding sources). To start with, citizens' benefits were operationalized as a significant facilitator enhancing the public participation in CS initiatives. As a general statement, we identified that CS initiatives were aiming to benefit the participants, but also to contribute to the development of science as well as to the preservation of socio-ecological systems. More specifically, Table 1 clearly illustrates that citizens provided emphasis on educational (34\%) and interpersonal/social benefits $(29 \%)$, rather than targeting on their emotional/physical/personal development or other hobby-related benefits ( $\sim 5-15 \%$ in each category). Aligned with these findings, one of the reviewed studies reporting on the Project FeederWatch, highlighted that "The main benefit many interviewees $(N=60)$ perceive ... include personal benefits (such as enjoying the experience or finding it relaxing), experiencing nature, and sharing the experience with others (i.e., social interactions)." [64] (p. 302).

On a different note, as shown in Table 1, the main motivation underlying citizen participation in nature-based/environmental CS initiatives, was the personal, psychological, and physiological enhancement $(18 \%)$, along with the desire of participants to contribute to the environment $(16 \%)$, followed by the social support (16\%), the educational $(12 \%)$, and understanding (11\%) motives. The least reported motivations included fun, and other protection and value-related motives $(<10 \%$ in each category).

The main goals mentioned by most of the participants were to contribute to science $(23 \%)$, connect with nature $(21 \%)$, and achieve stewardship of the natural world $(20 \%)$, with learning goals (21\%) being an integral part, as opposed to any physical goal from their participation in a CS initiative $(<10 \%)$. A questionnaire created to evaluate Sea Search members' motivations, benefits, and goals, exploited during our review, reports for instance on the following outcomes [65] (p. 450): (i) "Sea Search volunteers agreed that they feel good emotionally and mentally during an activity" (ii) "Sea Search volunteers also agreed that being in the marine environment during an activity is peaceful and gives a sense of calm" (iii) "Volunteers enjoy being part of the Sea Search group and socializing with other volunteers during the monitoring activity". 
Table 1. Relative frequencies and indicative statements for the typologies of "Benefits", "Motivations", "Goals" and "Constraints" of citizens in CS initiatives.

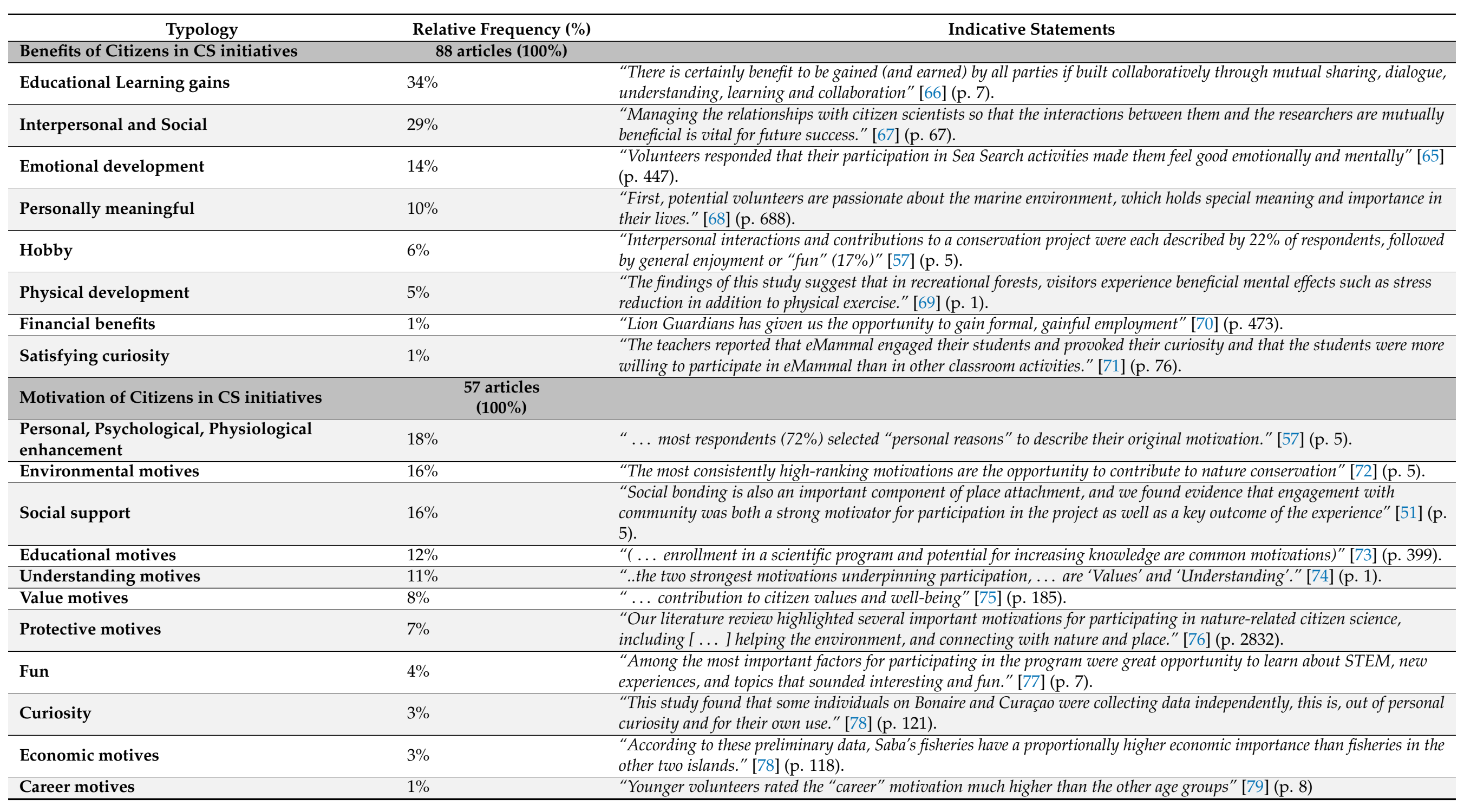


Table 1. Cont.

\begin{tabular}{|c|c|c|}
\hline Typology & Relative Frequency (\%) & Indicative Statements \\
\hline Teaching & $1 \%$ & "... desire to teach others about bees or citizen science" [58] (p. 42). \\
\hline Competition & $\mathrm{N} / \mathrm{A}$ & - \\
\hline Goals of Citizens in CS initiatives & $\begin{array}{l}44 \text { articles } \\
(100 \%)\end{array}$ & \\
\hline Contribute to science & $23 \%$ & "Wanting to 'contribute towards research efforts' was the most frequently mentioned theme" [74] (p. 4). \\
\hline Connect with nature & $21 \%$ & "wanting to work close to nature" [80] (p. 116). \\
\hline Learning goals & $21 \%$ & "I need to learn more about small bird ID, this will help me" [64] (p. 299). \\
\hline Contribute to stewardship of the natural world & $20 \%$ & $\begin{array}{l}\text { "This was often spoke of in terms of wanting to engage more closely with the waterfront and to bring others into processes of } \\
\text { environmental stewardship." [51] (p. 5). }\end{array}$ \\
\hline Educate others & $9 \%$ & $\begin{array}{l}\text { "A total of 98\% }(n=306) \text { of active COASST participants surveyed self-reported communicating to others about the } \\
\text { program..." [81] (p. 483). }\end{array}$ \\
\hline Physical exercise & $3 \%$ & $\begin{array}{l}\text { "The citizen scientists then leveraged their findings to advocate with local decision-makers for specific community } \\
\text { improvements to promote physical activity." [82] (p. 1). }\end{array}$ \\
\hline Relaxation & $3 \%$ & $\begin{array}{l}\text { "Private users usually observe nesting online for relaxation, and they may also participate directly in analysing the videos." } \\
\text { [83] (p. 5). }\end{array}$ \\
\hline $\begin{array}{l}\text { Constraints of Citizens Participation in CS } \\
\text { initiatives }\end{array}$ & $\begin{array}{l}38 \text { articles } \\
(100 \%)\end{array}$ & \\
\hline Design and other implementation issues & $31 \%$ & $\begin{array}{l}\text { "The present study didn't evaluate the long-term effectiveness of the participation in the monitoring program, since the } \\
\text { post-questionnaire was filled in during the last day of the volunteers' holiday." [84] (p. 12). }\end{array}$ \\
\hline Time consuming & $15 \%$ & $\begin{array}{l}\text { "In general, personal costs in terms of time, energy (i.e., effort) and financial resources to be spent were seen as an obstacle" } \\
\text { [78] (p. 124). }\end{array}$ \\
\hline Biases & $15 \%$ & "... a small number expressed concerns about targeting of marine species by others" [85] (p. 1). \\
\hline Lack of recognition of citizens' contributions & $9 \%$ & "The most common aspect was a lack of reward:" [62] (p. 330). \\
\hline Specialist equipment and knowledge & $8 \%$ & $\begin{array}{l}\text { "Limitations of our system include ... different orientations of the badge and camera to the lighting source while capturing } \\
\text { an image for calculation." [86] (p. 577). }\end{array}$ \\
\hline Funding & $7 \%$ & "... this was partly due to lack of funding" [87] (p. 163). \\
\hline Lack of scientific expertise & $6 \%$ & "... nearly a quarter cited a need for more training and general difficulty in following the protocol" [58] (p. 43). \\
\hline Lack of best practices & $5 \%$ & "The present study didn't evaluate the long-term effectiveness of the participation in the monitoring program" [84] (p. 12). \\
\hline Technological difficulties & $2 \%$ & "That is, the most frequently mentioned potential barriers were considered to be the technical design" [85] (p. 9). \\
\hline Limited communication between participants & $2 \%$ & "... provides limited communications between scientists and volunteers." [63] (p. 4). \\
\hline Institutional politics & $\mathrm{N} / \mathrm{A}$ & - \\
\hline Disabilities/Special educational needs & $\mathrm{N} / \mathrm{A}$ & - \\
\hline
\end{tabular}


On the other hand, as part of this review study, we aimed to shed light on the barriers affecting citizen participation in a CS initiative. In this context, during the decoding of the reviewed studies referring to the constraints of citizen participation in CS initiatives (Table 1), it is clear to see that the design and other implementation issues ( $31 \%)$, along with time limitations (15\%), were among the major barriers in CS initiatives. In addition, biases related to data validity $(15 \%)$ and lack of recognition $(9 \%)$, the use of specialist equipment and knowledge $(8 \%)$, and lack of funding $(7 \%)$ were also reported, as opposed to the least significant constraints $(<6 \%)$ which relate to the scientific expertise and the use of best practices by the CS initiatives. On this matter, as also highlighted in a recent study included in this review, for the purpose of the FeederWatch CS initiative, "The fee may be a barrier for some potential participants. While many interviewees admitted the amount is not substantial, some were surprised a fee is charged at all.", "Time is the leading barrier to interviewees' involvement [64] (p. 304).

\subsection{Environmental Citizenship in Citizen Science Initiatives}

An emerging question in our study is whether CS initiatives can endorse forms of participation which can support and promote environmental citizenship. An overview of the dimensions, scales and spheres of the environmental actions reported in the reviewed CS initiatives is shown in Figure 7. During our systematic literature review, it was found that most of the CS initiatives targeted the "individual" (66\%) over the "collective" (34\%) actions of environmental citizenship. In addition, these environmental actions primarily took place on the "local" scale (63\%) and to a lesser extent on the "national" and "global" scale (28 and 9\%, respectively). The actions of environmental citizenship reported in the CS initiatives were mostly included in the "private" sphere $(70 \%)$ rather than in the "public" sphere $(30 \%)$. A relevant work exploited for the purposes of our review, related to a survey and an interview of participants in the COASST citizen science project, precisely states: " ... conservation literate citizens develop a schema to prioritize impacts to their local environment, which allows them to move from a nonspecific sense of fear about environmental degradation to a sense of which action or actions are practicable and efficacious. Such a schema might be based on the greatest impacts at a larger scale (regional and global), the greatest impacts at the local scale, or impacts the individual has some ability to combat." [81] (p. 485). The promotion of Environmental Citizenship outcomes are also identified and presented in Figure 7, where (i) developing healthy relationship with nature ( $40 \%$ ), (ii) solve environmental problems (31\%), and (iii) prevent new environmental problems (24\%) were the top three outcomes reported in the reviewed CS initiatives. 
- EEC Outcomes

- Dimensions

- Spheres

- Scales

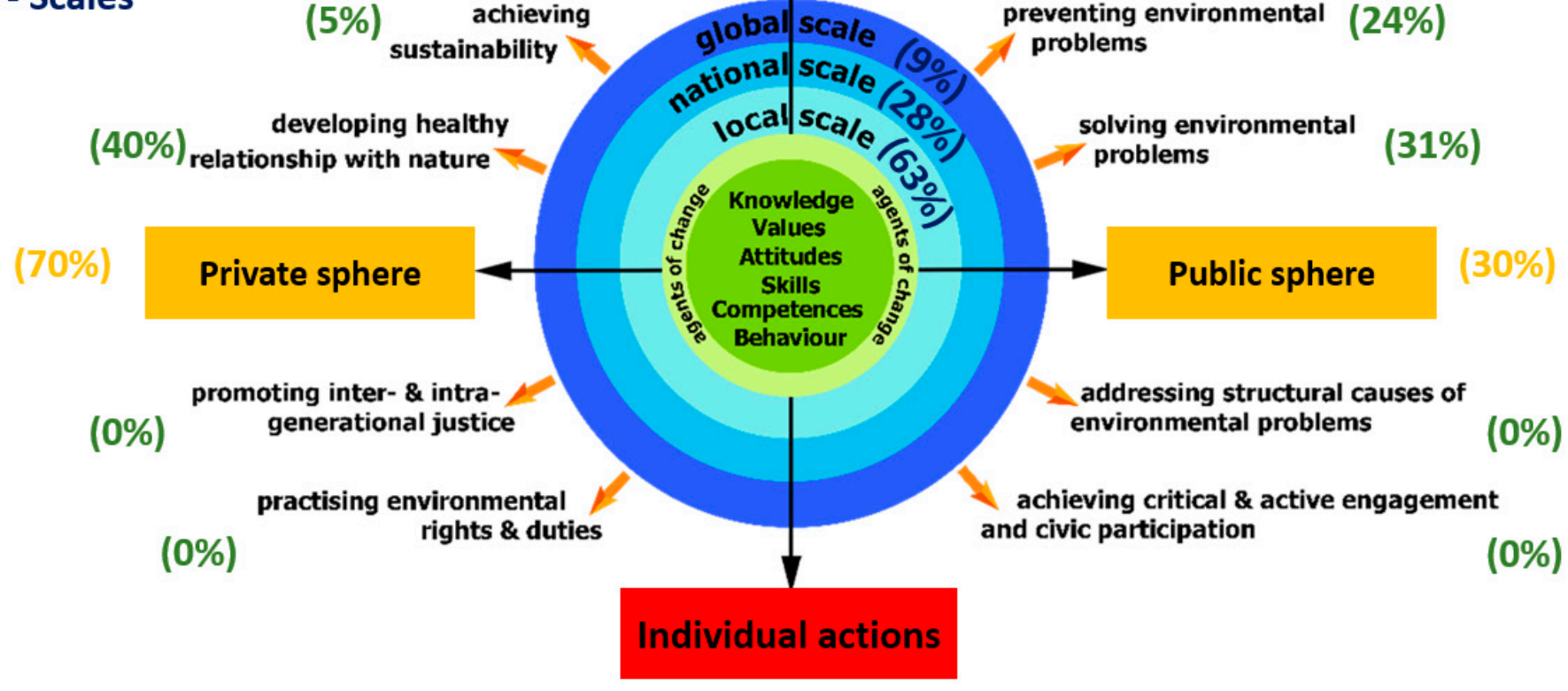

(34\%)

Figure 7. Dimensions, spheres and scales as the environmental citizenship actions $(\mathrm{N}=33)$ as well as the environmental citizenship outcomes $(\mathrm{N}=17)$ promoted by the reviewed CS initiatives (Source Modified: [49]).

\section{Discussion}

CS initiatives, and especially environmental and nature-based ones, have become an established scientific practice in recent decades. They can serve as a springboard towards the increase of citizens' participation in scientific processes, and the democratization of science, while also contributing to a broader, more inclusive, and more active socio-political participation of citizens. In this context, this study presents a systematic review of the available empirical research on citizens' participation in environmental and nature-based CS. More specifically, the participatory aspects of a total of 119 CS initiatives were analysed on the basis of four research questions set, to shed light on: (a) exclusion and inclusion demographic factors, (b) CS models and practices defining citizens' participation, (c) facilitators and constraints of citizen's participation, and (d) participation forms contributing to environmental citizenship. What follows is the discussion of our findings per research question, guiding this review study.

\subsection{Exclusion and Inclusion Demographic Factors}

\subsubsection{Highly Educated Younger Adults and U18 People without Gender Limitations}

At first, we sought to examine the demographic make-up of citizens participating in CS initiatives, as this could lead to potential inclusion and exclusion factors. During our systematic literature review, we did not find any limitations in terms of gender, as both males and females were able to participate in CS initiatives. However, based on the available literature, there are cases of gender inequalities within CS initiatives. For example, in two ornithology CS initiatives operated in the UK, which were studied by Edwards et al. (2018), 83\% of respondents were male [88]. This shows the need for more "inclusive" approaches which would be of benefit for CS initiatives, avoiding any discrimination and inequality. In addition, according to the results of our review, most of the participants were adults, and the number of initiatives where U18 people participated was three times 
lower. This finding underlines that environmental and nature-based CS initiatives, until now, do not focus on school age participants to an extended degree. These results were also discussed in other studies with similar findings [88]. However, as other recent studies have argued, CS initiatives have great potential as an educational tool which can be used more widely and in more depth for educational purposes as well as for school-age children [89]. The educational level of citizens participating in CS initiatives seems to also be a crucial factor. In fact, and in line with Edwards et al.'s (2018) findings, where $67 \%$ of respondents hold a university degree, our findings also provided empirical substantiation that educated people ( $>80 \%$ with at least higher school diploma) mostly participated in CS initiatives. Our demographic findings are also in agreement with the findings derived from a survey contacted by the PEW Research Centre in the USA [90], where younger, more educated U.S. adults were more likely to participate in CS initiatives. In addition, in an evaluation of the educational impact of CS project conducted by the Cornell Lab of Ornithology, it was revealed that the age of seed preference is in the range of our findings, where participants tended to be older and well educated than the general population, with an interest in science [91]. Overall, it seems that the results of this review confirm the trend that naturebased and environmental CS initiatives were dominated by "elite" highly educated groups of people [6]. This fact refers to cultural hegemony of the well-educated academically skilled proportion of the population [92].

\subsubsection{EU and American Domination of Mainly Local Scale CS Initiatives}

The CS initiatives reported in the majority of the reviewed articles appeared to be local and national based. However, it is of importance to cover a greater geographical scale via the formation of continental and international CS initiatives, in order to reduce discrimination and in parallel to increase uniformity at the environmental level [93]. This geographic imbalance was raised by the fact that most of the CS initiatives were applied in America and Europe, with very few initiatives taking place in Oceania, Africa, and Asia. As described in the literature $[29,43,94]$, and also as found during our systematic literature review, the geographic discrepancy on citizens' participation might be attributed to the lack of national funding and other continental constraints, including but not limited to demographic and socio-political factors [95]. In the same line, participants originated from certain ethnic, racial, and socio-economic groups, which are historically underrepresented, are less likely to contribute in CS initiatives [96]. For instance, in a study with more than 300 biodiversity CS initiatives examined, the participants were white $(88.6 \%)$, while $6.1 \%$ were Hispanic and $4.6 \%$ were Asian $[97,98]$. Thus, a possible explanation, given once again in the literature, indicates that this discrimination might be due either to lack of funding or due to limited impact that citizens have on decision- and policy-making on these geographic regions and continents [99]. This is not the case in Europe and the US, as key players with a central role in the field of CS, dedicating funding for research and development of CS initiatives as well as for capacity building activities.

\subsubsection{Academic Driven CS Initiatives}

During our review study, we identified that most of the nature and environment-based CS initiatives were coordinated by academic institutions, followed by NGOs and to a lesser extent by governmental organisations, with most of the funding derived by the latter two organisations. This is important, especially after considering that national governments are the ideal level to promote public awareness and decision-making, not only within nations but also on a broader dimension [43]. In addition, the fact that academic driven initiatives are leading to more publications, in comparison to the NGOs-coordinated ones, is that the latter might not have the time or motivation to write scientific articles about their initiatives. Even though CS initiatives are mostly grounded on a volunteer base, the financial support is still very important during all the stages of the initiative (pre- and post- related activities, such as data collection, data control, training, dissemination, etc.). Therefore, in order to achieve sustainability and enhancement of scientific and societal learning, co-funding 
(among different sources or countries) should be considered imperative $[29,100]$. As the National Research Council (NRC) of the US states in the "Ecological for the nation" book, in order to achieve long-term sustainability of a CS initiative, multiple funding sources are needed, especially derived from universities and NGOs [101].

\subsection{Emerging Models and Practices of CS Initiatives}

4.2.1. Nature Conservation and Awareness Prioritization towards Scientific Content and Knowledge

In order to effectively design CS initiatives and to establish an engagement framework, it is important to track all the current and emerging models and practices along with the forms of participation. Most of the CS initiatives studied had as overarching aims nature conservation, awareness, education, and environmental management, on the local scale. The gravity of each of the above-mentioned overarching aims was also drawn in the Word Cloud by Cunha et al. (2017), where conservation, education, and environmental management were of high priority and mostly reported in the peer-reviewed papers analysed by the authors [43]. Additionally, during our systematic literature review we were able to identify few science learning related goals within the CS initiatives, which were aiming towards understanding the scientific content and knowledge and engaging citizens in scientific practices. In these few cases, science learning promoted scientific literacy in a way that citizens acquire knowledge, understanding the nature of science and raising awareness, as previously raised by various research groups [102,103].

\subsubsection{Participation as Individuals Acting as Data Collectors in the Long-Term}

Data collection, mostly derived from citizens, is an important aspect for a CS initiative, as it can affect its data quality and reputation [104,105]. Based on our findings, the majority of CS initiatives used single persons or small groups of citizens for the collection of data, multiple times, over an extended time period. This finding has also emerged in the review studies of other research groups, which focused on different research scopes and contexts [43]. It can be understood that these findings also fit very well with the forms of citizens' participation (i.e., volunteers), the duration of engagement (minimum, 1-10 h) as well as with the main constraints reported (time consuming process), as according to Bloom and Crowder (2020), citizens prefer to manage their time and their participation in the CS initiatives according to their schedule with the least possible commitment [106]. On the other hand, as well reported in the literature, contributions are primarily driven by those who return for multiple days, increasing in that way the quality and quantity of data collection, and its impact towards CS outcome expectations [107].

\subsubsection{Citizens in Volunteering form Following the Contributory Model of Participation}

Our findings regarding the forms of citizens' participation, reveal that citizens were mostly involved on a volunteering basis and were engaged only with data, rather than actively engaged with all the stages of the process underlying the CS initiative. Additionally, most of the reviewed CS initiatives were contributory, and to a lesser degree contractual and collaborative, with no reports on co-created and collegial ones. The latter trend is in agreement with citizens' views on what can hold them off into participating in a CS initiative, as collaborative initiatives are by definition designed by scientists with citizens to contribute mostly on data gathering, data analysis, and dissemination of results, as will be discussed in the following section [2]. These results are in line with other relevant studies [7]. More specifically, there are various studies reporting that citizens were involved only in data collection, rather than data analysis and interpretation, which was performed by professional scientists [61]. The active engagement of citizens throughout the whole duration of the CS initiative, including decision making and management of the CS initiative, it is a relatively recent trend and becomes mandatory in order to increase the impact of CS and decrease the discrimination factors affecting citizens' participation, thus leading to more inclusive and democratic science procedures $[2,108]$. 


\subsubsection{Digitalisation as the Media of Communication}

The use of digital technologies is considered crucial nowadays, as it (i) can engage nontraditional audiences, (ii) stand for communication purposes with and among participants, and thus (iii) have a direct impact on the participatory aspects of CS initiatives [109]. Based on our review, various modes and topics of communications were identified, while the use of digital technologies seemed to improve the control and quality of the data collection. At the same time, according to our findings, digital technologies seemed to motivate citizens, thus contributing to the engagement of broader audiences. Web-based platforms and in-person meetings emerged as the primary means to support the communication of the CS initiatives' participants on aspects such as data collection, training, and recruiting, replacing the more traditional communication venues such as the regular newsletter and the telephone. In addition, previous studies showed that communication among participants is considered one of the main motivational aspects for the continuation of a CS initiative [110]. Therefore, emerging technologies constitute an ideal choice towards the promotion of a CS initiative as well as towards speeding decision-making [111]. For this reason, emerging technologies are well explored in the recent literature for their influence on data collection, management, control, and communication in CS initiatives [112-115].

\subsection{Facilitators and Constraints of Citizens' Participation}

\subsubsection{Citizens Are Motivated by Learning Gains along with Interpersonal and Social Benefits}

The majority of the reviewed articles reported that citizens had mainly educational, interpersonal, and social benefits, instead of physical development or hobby and entertainment benefits. These results are in line with the existing literature, in which it is repeatedly reported that it is vital to identify facilitators (motivations, benefits, goals) affecting citizens' participation in CS initiatives [116-119]. According to our results, the primary motives underlying public participation in a CS initiative were the citizens' personal enhancement, as well as environmental and social support. The citizens were motivated towards participating in a CS initiative for their personal development, but also for learning more about various environmental issues as well as for being socialised. It is worth mentioning that our findings are in agreement with the literature [120-122]. For example, McDougle et al. (2011) reported that young adults were motivated to volunteer for social reasons [123]. Our results are in accordance with other studies which showed that face-to-face interactions, the level of personal investment and motivations to socialise can positively influence the level of participation in a CS initiative $[124,125]$. The specific interest in a particular scientific topic could be also an important motivation for public participation in CS initiatives. For example, an intrinsic interest in birds can attract participants in bird monitoring CS initiatives [126].

\subsubsection{Contribute to Science and Connecting with Nature as Citizens' Primary Goals}

Considering citizens' goals for participation, most reviewed studies reported that citizens were aiming to contribute to science, connect with nature and take actions towards the stewardship of the natural world, along with the personal learning gains. As recently reported in a book chapter titled "Citizen Science: Connecting to Nature Through Networks", and in-line to our findings, the main goals of participants in CS initiatives were to contribute to science research and connect with nature [127]. Therein, a framework was set in order to promote partnership between participants and to endorse participation based on citizens' personal interests and goals. Complementarily, in an interesting CS initiative (Connect with Nature programme) designed and implemented by the Emirates Nature-WWF, 2020, the stakeholders were particularly aiming towards connecting United Arab Emirates residents with nature, thus promoting active participation and contribution to science.

\subsubsection{Constraints Arising from the Design to the Implementation of CS Initiatives}

Citizen Science, nowadays, is widely used in academia as method of retrieving research data from the crowd, and thus various limitations and biases should be targeted 
and controlled [121]. Additionally, as the case studies published in the available literature referred to successful CS initiatives which were mostly beneficial for the participants, there is still limited understanding of the barriers leading participants not to participate or abort from the initiative. Based on our findings, the highest constraints of citizens' participation in CS initiatives were attributed to the design/implementation issues as well as the fact that the initiatives required significant time spent from the participants, leading them in this way to aversion. Similar trends were observed in a recent crowdsourcing systematic review report published by Strang and Simmons (2018), where interviewees pointed to the importance of having clear instructions, consistency on the feedback from the initiative coordinators, and meeting the time frames set during the design of the initiative. However, in the same study, only $20 \%$ of the participants completed the initiative, with the rest aborting it at various stages [34]. Thus, inadequate design and implementation of a CS initiative, by compromising funding sources and the time requirements, could potentially lead participants not to be satisfied from the initiative. In this way, data quality might be impacted [128,129]. On the other hand, careful design and implementation of CS initiatives could be the opportunity to contribute to the active engagement of environmentally concerned citizens [130].

\subsection{Citizen Participation in Citizen Science for Environmental Citizenship}

The degree of inclusiveness, the depth of democracy and participation, the issues of equality as well as the issues of intra- and inter-generational justice in CS initiatives are of particular importance for the promotion of environmental citizenship [49]. Based on the results of this literature review, CS initiatives related to environmental and nature-based issues mainly promote efforts to develop a healthy relationship with nature, as well as to solve existing or prevent new environmental problems (e.g., biodiversity loss, air pollution, etc.). However, their focus on environmental citizenship as well as their attempt to fostering a deep civic participation and active engagement with society could be further integrated. In addition, their contribution to the suppression of the structural causes of environmental problems, but also to the promotion of intra- and inter-generational justice, is almost absent. Focusing on the level of environmental citizenship actions, the reviewed CS initiatives deal mainly with environmental citizenship actions lying at the individual dimension, while ignoring collective actions as well as actions in the public sphere. Based on our results, we recognize that, in many cases, CS initiatives contribute to a local connection with local civic actions (place-based approach) or sometimes to national actions, but there are only few CS initiatives promoting environmental citizenship actions on the global scale.

\section{Limitations of the Study}

Although we aimed at providing a comprehensive systematic literature review, in order to contribute to the improvement of future nature-based and environmental CS initiatives and to conceptualize the whole spectrum affecting participation in CS initiatives, some limitations should not be overlooked. The use of search engines for retrieving scientific articles by filtering the available literature with specific keywords has risks, and should be treated carefully in order to draw valid conclusions [32]. In addition, our approach resulted in the review of academic articles in English language within the last two decades (2000-2020), without covering other languages. This approach led us to retrieve articles from various areas with newly established scientific data mostly from academia [131,132]. However, the filtering of studies according to time of publication and English language might lead to chronological and geographic discriminations, respectively [133].

\section{Conclusions, Implications and Future Research}

There has been an increase of interest in the design and implementation of nature and environmental-based CS initiatives in the last two decades. However, there is still a lack of understanding of important aspects in relation to citizens' participation. Due to the multifaceted complexity of CS, participants have to converge their views and needs, 
understand each other, and thus jointly and actively support the establishment of such inclusive and participatory CS initiatives which can act as a venue of citizen empowerment towards environmental citizenship.

Based on our findings, nature and environmental-based CS initiatives applied in the last two decades present several weaknesses, and it seems that future endeavours in the field should take into consideration various aspects affecting citizen participation. Notably, since most of the prior research has not attempted to review, synthesize, and compare projects and best practices focusing on the concept of participation, many of our outcomes could be treated as unique, to the best of our knowledge.

Focusing on the inclusion and exclusion demographic factors, CS initiatives aiming to cover greater geographical scale should target on a more continental and global scale. In this way it will be possible to engage more Oceanian, African, and Asian populations, thus limiting any geographic discriminations. Demographic trends also revealed the necessity to engage more U18 citizens, and in the cases where CS initiatives aim towards education, further adult participation, thereby forming a society educated from an early age. Particular attention should also be given to more inclusive approaches, avoiding any discrimination such as those of gender, educational level, and access in digital technology. Additionally, it is noteworthy to be mentioned that it is important for CS initiatives to give voice to underrepresented groups and societies, in groups with disabilities, and low skilled/low achievers' groups. The learning potential of CS initiatives is of great significance and should be given more emphasis in future research studies, as it can allow scientists and communities to have access to further insights, thus facilitating policy- and decisionmaking. Strengthening the coordination and funding sources of CS initiatives is considered of paramount importance. These decisions should not be only made by academic institutes but also by NGOs and governmental organisations, as the latter two constitute an ideal leverage for the promotion of public awareness, policy- and decision-making, though lag on disseminating their findings in the form of scientific publications.

Considering the emerging models and practices of CS initiatives identified during our systematic literature review, it seems that CS initiatives should direct their overarching aims towards "actions" and "improving methods and tools" required for better data management and quality. The latter highlights the importance of setting certain overarching aims on a CS initiative, including but not limited to the nature conservation, awareness, education, and environmental management. Additionally, considering the science learning related goals of CS initiatives, these should be also designed in order to spark the excitement of citizens, and along with scientific literacy and knowledge gains, to contribute to an increase in their understanding of the nature of science. Therefore, future research can focus on the needs of citizens and the design of models and practices, which can be valuable for key stakeholder to design and implement CS initiatives. Such models and practices will promote citizens' activities in addition to "passive" data collection and submission.

Understanding the facilitators (e.g., benefits, motivations, goals) and the constraints of participants in CS initiatives will advance the design and implementation of future research in the field, while following important scientific practices. As shown in this review, citizens reported that their primary benefits were to educate and socialise themselves. Thus, in combination with the main motives identified during our review, we propose that future CS initiatives should take into account the personal, psychological, and physiological aspects of participation, as well as the citizens' educational, and social expectations. Recognizing citizens' benefits and motivations will help CS initiatives efforts towards approaching citizens' goals such as the contribution to science, stewardship of the natural world, and connection with nature. To reveal positive and negative impacts of CS initiatives, it is also important first to overcome (at least) the main reported constraints related to the design and implementation issues and to create CS initiatives with less time requirements.

Enhancement of democratization of CS initiatives is of particular importance. Broadening citizens' participation through more participative and co-design models of participation is crucial. Future CS initiatives should not target engage citizens only with data but with the 
whole process, thus achieving a long-term engagement. The latter might also be enhanced by the appropriate design of models and practices of CS initiatives which primarily will use not only single persons as volunteers, but also groups of citizens or communities, thus creating a sustainable, pleasant, and productive environment. In addition, incorporating socio-political and socio-cultural actions will help to promote awareness, nature conservation, and develop environmental citizenship with more focus on environmental citizenship actions situated in the collective dimension, public sphere, as well as on the national and global scale. Therefore, based on our findings, much more efforts should be made in order to achieve a sustain contribution and engagement, which can eventually lead to more aware citizens, participating actively (either physically and/or intellectually) throughout the whole duration of the project.

Author Contributions: Conceptualization, A.C.H. and D.P.-H.; methodology, M.A.V., A.C.H., D.P.H., A.A. and Y.G.; software, M.A.V.; validation, A.C.H., D.P.-H. and Y.G.; formal analysis, A.C.H.; investigation, M.A.V. and A.A.; resources, M.A.V., A.C.H., D.P.-H., A.A. and Y.G.; data curation, M.A.V., A.A. and D.P.-H.; writing—original draft preparation, M.A.V.; writing-review and editing, M.A.V., A.C.H., D.P.-H., and Y.G.; visualization, A.C.H. and D.P.-H.; supervision, A.C.H. and D.P.-H.; project administration, M.A.V.; funding acquisition, A.C.H. and D.P.-H. All authors have read and agreed to the published version of the manuscript.

Funding: This research was funded by European Union's Horizon 2020 research and innovation programme under grant agreement No. 872557, EnviroCitizen Project.

Institutional Review Board Statement: Not applicable.

Informed Consent Statement: Not applicable.

Data Availability Statement: No new data were created or analyzed in this study. Data sharing is not applicable to this article.

Acknowledgments: This study is partly inspired by the ENEC Cost Action -European Networks for Environmental Citizenship-CA16229 supported by COST (European Cooperation in Science and Technology-Horizon 2020).

Conflicts of Interest: The authors declare no conflict of interest.

\section{References}

1. Bonney, R.; Phillips, T.B.; Ballard, H.L.; Enck, J.W. Can Citizen Science Enhance Public Understanding of Science? Public Underst. Sci. 2016, 25, 2-16. [CrossRef] [PubMed]

2. Shirk, J.L.; Ballard, H.L.; Wilderman, C.C.; Phillips, T.; Wiggins, A.; Jordan, R.; McCallie, E.; Minarchek, M.; Lewenstein, B.V.; Krasny, M.E.; et al. Public Participation in Scientific Research: A Framework for Deliberate Design. Ecol. Soc. 2012, 17. [CrossRef]

3. Bonney, R.; Cooper, C.; Dickinson, J.; Kelling, S.; Phillips, T.; Rosenberg, K.V.; Shirk, J. Citizen Science: A Developing Tool for Expanding Science Knowledge and Scientific Literacy. BioScience 2009, 59, 977-984. [CrossRef]

4. Fritz, S.; See, L.; Carlson, T.; Haklay, M.M.; Oliver, J.L.; Fraisl, D.; Mondardini, R.; Brocklehurst, M.; Shanley, L.A.; Schade, S.; et al. Citizen Science and the United Nations Sustainable Development Goals. Nat. Sustain. 2019, 2, 922-930. [CrossRef]

5. Irwin, A. Citizen Science: A Study of People, Expertise, and Sustainable Development; Routledge: London, UK, 1995.

6. Oesterle, J.; Upadhyay, B.; Brown, J.C.; Vernon, M. Citizen Science: A Path to Democratic and Sociopolitically Conscious Science. In Handbook of Theory and Research in Cultural Studies and Education; Springer: Cham, Switzerland, 2020; pp. 1-30.

7. Wiggins, A.; Crowston, K. Goals and Tasks: Two Typologies of Citizen Science Projects. In Proceedings of the 201245 th Hawaii International Conference on System Sciences, Maui, HI, USA, 4-7 January 2012; pp. 3426-3435.

8. Dickinson, J.L.; Shirk, J.; Bonter, D.; Bonney, R.; Crain, R.L.; Martin, J.; Phillips, T.; Purcell, K. The Current State of Citizen Science as a Tool for Ecological Research and Public Engagement. Front. Ecol. Environ. 2012, 10, 291-297. [CrossRef]

9. Pretty, J.; Ball, A.; Benton, T.; Guivant, J.; Lee, D.R.; Orr, D.; Pfeffer, M.J.; Ward, H. The SAGE Handbook of Environment and Society; SAGE Publications Ltd.: London, UK, 2021.

10. Yadav, P.; Darlington, J. Conceptual Frameworks for Building Online Citizen Science Projects. Hum. Comput. 2016, 3, $213-223$. [CrossRef]

11. Jordan, R.C.; Gray, S.A.; Howe, D.V.; Brooks, W.R.; Ehrenfeld, J.G. Knowledge Gain and Behavioral Change in Citizen-Science Programs. Conserv. Biol. 2011, 25, 1148-1154. [CrossRef]

12. Lostarnau, C.; Oyarzún, J.; Maturana, H.; Soto, G.; Señoret, M.; Soto, M.; Rötting, T.S.; Amezaga, J.M.; Oyarzún, R. Stakeholder Participation within the Public Environmental System in Chile: Major Gaps between Theory and Practice. J. Environ. Manag. 2011, 92, 2470-2478. [CrossRef] 
13. O'Faircheallaigh, C. Public Participation and Environmental Impact Assessment: Purposes, Implications, and Lessons for Public Policy Making. Environ. Impact Assess. Rev. 2010, 30, 19-27. [CrossRef]

14. Haklay, M. Citizen Science and Volunteered Geographic Information: Overview and Typology of Participation. In Crowdsourcing Geographic Knowledge: Volunteered Geographic Information (VGI) in Theory and Practice; Sui, D., Elwood, S., Goodchild, M., Eds.; Springer: Dordrecht, The Netherlands, 2013; pp. 105-122. ISBN 978-94-007-4587-2.

15. Chandler, M.; See, L.; Copas, K.; Bonde, A.M.Z.; López, B.C.; Danielsen, F.; Legind, J.K.; Masinde, S.; Miller-Rushing, A.J.; Newman, G.; et al. Contribution of Citizen Science towards International Biodiversity Monitoring. Biol. Conserv. 2017, 213, 280-294. [CrossRef]

16. Sullivan, D.P.; Winsnes, C.F.; Akesson, L.; Hjelmare, M.; Wiking, M.; Schutten, R.; Campbell, L.; Leifsson, H.; Rhodes, S.; Nordgren, A.; et al. Deep Learning Is Combined with Massive-Scale Citizen Science to Improve Large-Scale Image Classification. Nat. Biotechnol. 2018, 36, 820-832. [CrossRef] [PubMed]

17. Van Swaay, C.A.M.; Nowicki, P.; Settele, J.; van Strien, A.J. Butterfly Monitoring in Europe: Methods, Applications and Perspectives. Biodivers. Conserv. 2008, 17, 3455-3469. [CrossRef]

18. Brodie, E.; Cowling, E.; Nissen, N.; Paine, A.E.; Jochum, V.; Warburton, D. Understanding Participation: A Literature Review; National Council for Voluntary Organisations: London, UK, 2009.

19. Dickinson, J.L.; Zuckerberg, B.; Bonter, D.N. Citizen Science as an Ecological Research Tool: Challenges and Benefits. Annu. Rev. Ecol. Evol. Syst. 2010, 41, 149-172. [CrossRef]

20. Wiggins, A.; Crowston, K. From Conservation to Crowdsourcing: A Typology of Citizen Science. In Proceedings of the 2011 44th Hawaii International Conference on System Sciences, Kauai, HI, USA, 4-7 January 2011; pp. 1-10.

21. Arnstein, S.R. A Ladder of Citizen Participation. J. Am. Inst. Plan. 1969, 35, 216-224. [CrossRef]

22. Bonney, R. Citizen Science: A Lab Tradition. Living Bird 1996, 15, 7-15.

23. Eitzel, M.V.; Cappadonna, J.L.; Santos-Lang, C.; Duerr, R.E.; Virapongse, A.; West, S.E.; Kyba, C.; Bowser, A.; Cooper, C.B.; Sforzi, A.; et al. Citizen Science Terminology Matters: Exploring Key Terms. Citiz. Sci. Theory Pract. 2017, 2. [CrossRef]

24. Chari, R.; Matthews, L.J.; Blumenthal, M.S.; Edelman, A.F.; Jones, T. The Promise of Community Citizen Science; RAND Corporation: Santa Monica, CA, USA, 2017.

25. Kofinas, G.P. Adaptive Co-management in Social-Ecological Governance. In Principles of Ecosystem Stewardship: Resilience-Based Natural Resource Management in a Changing World; Folke, C., Kofinas, G.P., Chapin, F.S., Eds.; Springer: New York, NY, USA, 2009; pp. 77-101. ISBN 978-0-387-73033-2.

26. Stewart, J.M.P.; Sinclair, A.J. Meaningful Public Participation in Environmental Assessment: Perspectives from Canadian Participants, Proponents, and Government. J. Environ. Assess. Policy Manag. 2007, 09, 161-183. [CrossRef]

27. Asingizwe, D.; Poortvliet, P.M.; Koenraadt, C.J.M.; van Vliet, A.J.H.; Ingabire, C.M.; Mutesa, L.; Leeuwis, C. Why (Not) Participate in Citizen Science? Motivational Factors and Barriers to Participate in a Citizen Science Program for Malaria Control in Rwanda. PLoS ONE 2020, 15, e0237396. [CrossRef]

28. Martin, V.; Smith, L.; Bowling, A.; Christidis, L.; Lloyd, D.; Pecl, G. Citizens as Scientists: What Influences Public Contributions to Marine Research? Sci. Commun. 2016, 38, 495-522. [CrossRef]

29. Conrad, C.C.; Hilchey, K.G. A Review of Citizen Science and Community-Based Environmental Monitoring: Issues and Opportunities. Environ. Monit. Assess. 2011, 176, 273-291. [CrossRef]

30. Crocetta, F.; Gofas, S.; Salas, C.; Tringali, L.P.; Zenetos, A. Local Ecological Knowledge versus Published Literature: A Review of Non-Indigenous Mollusca in Greek Marine Waters. Aquat. Invasions 2017, 12, 415-434. [CrossRef]

31. Groulx, M.; Brisbois, M.C.; Lemieux, C.J.; Winegardner, A.; Fishback, L.A. A Role for Nature-Based Citizen Science in Promoting Individual and Collective Climate Change Action? A Systematic Review of Learning Outcomes. Sci. Commun. 2017, 39, 45-76. [CrossRef]

32. Mingers, J.; Leydesdorff, L. A Review of Theory and Practice in Scientometrics. Eur. J. Oper. Res. 2015, 246, 1-19. [CrossRef]

33. Prather, E.E.; Cormier, S.; Wallace, C.S.; Lintott, C.; Raddick, M.J.; Smith, A. Measuring the Conceptual Understandings of Citizen Scientists Participating in Zooniverse Projects: A First Approach. Astron. Educ. Rev. 2013, 12, 1-14. [CrossRef]

34. Strang, L.; Simmons, R.K. Citizen Science: Crowdsourcing for Systematic Reviews; The Healthcare Improvement Studies Institute: Cambridge, UK, 2018; ISBN 978-1-9996539-1-0.

35. Geoghegan, H.; Dyke, A.; Pateman, R.; West, S.; Everett, G. Understanding Motivations for Citizen Science: Final report on behalf of the UK Environmental Observation Framework; UK Environmental Observation Framework: Swindon, UK, 2016.

36. Skarlatidou, A.; Hamilton, A.; Vitos, M.; Haklay, M. What Do Volunteers Want from Citizen Science Technologies? A Systematic Literature Review and Best Practice Guidelines. J. Sci. Commun. 2019, 18. [CrossRef]

37. Leach, B.; Parkinson, S.; Lichten, C.A.; Marjanovic, S. Emerging Developments in Citizen Science: Reflecting on Areas of Innovation; RAND Corporation: Santa Monica, CA, USA, 2020.

38. Wiggins, A.; Crowston, K. Surveying the Citizen Science Landscape. First Monday 2014, 20. [CrossRef]

39. Silvertown, J. A New Dawn for Citizen Science. Trends Ecol. Evol. 2009, 24, 467-471. [CrossRef]

40. Halbritter, A.H.; De Boeck, H.J.; Eycott, A.E.; Reinsch, S.; Robinson, D.A.; Vicca, S.; Berauer, B.; Christiansen, C.T.; Estiarte, M.; Grünzweig, J.M.; et al. The Handbook for Standardized Field and Laboratory Measurements in Terrestrial Climate Change Experiments and Observational Studies (ClimEx). Methods Ecol. Evol. 2020, 11, 22-37. [CrossRef] 
41. Noss, R.F. Handbook of Citizen Science in Ecology and Conservation, 1st ed.; University of California Press: Oakland, CA, USA, 2020; ISBN 978-0-520-28477-7.

42. Trifonas, P.P. Handbook of Theory and Research in Cultural Studies and Education; Springer: Berlin/Heidelberg, Germany, 2019.

43. Cunha, D.G.F.; Marques, J.F.; Resende, J.C.D.; Falco, P.B.D.; Souza, C.M.D.; Loiselle, S.A. Citizen Science Participation in Research in the Environmental Sciences: Key Factors Related to Projects' Success and Longevity. An. Acad. Bras. Cienc. 2017, 89, $2229-2245$. [CrossRef]

44. Jørgensen, F.A.; Jørgensen, D. Citizen Science for Environmental Citizenship. Conserv. Biol. 2020. [CrossRef] [PubMed]

45. Jasanoff, S. States of Knowledge: The Co-Production of Science and the Social Order, 1st ed.; Routledge: London, UK, 2004; ISBN 978-0-203-41384-5.

46. Hadjichambis, A.; Reis, P.; Paraskeva-Hadjichambi, D.; Cincera, J.; Boeve-de Pauw, J.; Gericke, N.; Knippels, M.-C. Conceptualizing Environmental Citizenship for 21st Century Education; Springer: Berlin/Heidelberg, Germany, 2020; ISBN 978-3-030-20248-4.

47. National Academies of Sciences, Engineering, Medicine. Learning Through Citizen Science: Enhancing Opportunities by Design; Pandya, R., Dibner, K.A., Eds.; The National Academies Press: Washington, DC, USA, 2018; ISBN 978-0-309-47916-5.

48. Bela, G.; Peltola, T.; Young, J.C.; Balázs, B.; Arpin, I.; Pataki, G.; Hauck, J.; Kelemen, E.; Kopperoinen, L.; Van Herzele, A.; et al. Learning and the Transformative Potential of Citizen Science. Conserv. Biol. 2016, 30, 990-999. [CrossRef] [PubMed]

49. Hadjichambis, A.C.; Paraskeva-Hadjichambi, D. Education for Environmental Citizenship: The Pedagogical Approach. In Conceptualizing Environmental Citizenship for 21st Century Education; Hadjichambis, A.C., Reis, P., Paraskeva-Hadjichambi, D., Činčera, J., Boeve-de Pauw, J., Gericke, N., Knippels, M.-C., Eds.; Springer International Publishing: Cham, Switzerland, 2020; pp. 237-261. ISBN 978-3-030-20249-1.

50. Overdevest, C.; Orr, C.H.; Stepenuck, K. Volunteer Stream Monitoring and Local Participation in Natural Resource Issues. Hum. Ecol. Rev. 2004, 177-185.

51. Toomey, A.H.; Strehlau-Howay, L.; Manzolillo, B.; Thomas, C. The Place-Making Potential of Citizen Science: Creating SocialEcological Connections in an Urbanized World. Landsc. Urban Plan. 2020, 200, 103824. [CrossRef]

52. Moher, D.; Liberati, A.; Tetzlaff, J.; Altman, D.G.; Group, T.P. Preferred Reporting Items for Systematic Reviews and Meta-Analyses: The PRISMA Statement. PLoS Med. 2009, 6, e1000097. [CrossRef]

53. Gusenbauer, M.; Haddaway, N.R. Which Academic Search Systems Are Suitable for Systematic Reviews or Meta-Analyses? Evaluating Retrieval Qualities of Google Scholar, PubMed, and 26 Other Resources. Res. Synth. Methods 2020, 11, $181-217$. [CrossRef] [PubMed]

54. National Research Council. Learning Science in Informal Environments: People, Places, and Pursuits; Bell, P., Lewenstein, B., Shouse, A.W., Feder, M.A., Eds.; The National Academies Press: Washington, DC, USA, 2009; ISBN 978-0-309-11955-9.

55. Lavrakas, P. Encyclopedia of Survey Research Methods; Sage Publications Inc.: Thousand Oaks, CA, USA, 2021. [CrossRef]

56. Garcia-Marti, I.; Zurita-Milla, R.; van Vliet, A.J.H.; Takken, W.; Garcia-Martí, I.; Zurita-Milla, R.; van Vliet, A.J.H.; Takken, W. Modelling and Mapping Tick Dynamics Using Volunteered Observations. Int. J. Health Geogr. 2017, 16. [CrossRef] [PubMed]

57. Ng, C.S.; Duncan, J.R.; Koper, N. Who's "Hooting"? Motivations and Scientific Attitudes of Manitoban Citizen Science Owl Surveyors. Avian Conserv. Ecol. 2018, 13. [CrossRef]

58. Domroese, M.C.; Johnson, E.A. Why Watch Bees? Motivations of Citizen Science Volunteers in the Great Pollinator Project. Biol. Conserv. 2017, 208, 40-47. [CrossRef]

59. Rappold, A.G.; Hano, M.C.; Prince, S.; Wei, L.; Huang, S.M.; Baghdikian, C.; Stearns, B.; Gao, X.; Hoshiko, S.; Cascio, W.E.; et al. Smoke Sense Initiative Leverages Citizen Science to Address the Growing Wildfire-Related Public Health Problem. GeoHealth 2019, 3, 443-457. [CrossRef]

60. Elbroch, M.; Mwampamba, T.H.; Santos, M.J.; Zylberberg, M.; Liebenberg, L.; Minye, J.; Mosser, C.; Reddy, E. The Value, Limitations, and Challenges of Employing Local Experts in Conservation Research. Conserv. Biol. 2011, 25, 1195-1202. [CrossRef]

61. Lucky, A.; Savage, A.M.; Nichols, L.M.; Castracani, C.; Shell, L.; Grasso, D.A.; Mori, A.; Dunn, R.R. Ecologists, Educators, and Writers Collaborate with the Public to Assess Backyard Diversity in The School of Ants Project. Ecosphere 2014, 5. [CrossRef]

62. Aivelo, T.; Huovelin, S. Combining Formal Education and Citizen Science: A Case Study on Students' Perceptions of Learning and Interest in an Urban Rat Project. Environ. Educ. Res. 2020, 26, 324-340. [CrossRef]

63. Lowry, C.S.; Fienen, M.N.; Hall, D.M.; Stepenuck, K.F. Growing Pains of Crowdsourced Stream Stage Monitoring Using Mobile Phones: The Development of Crowdhydrology. Front. Earth Sci. 2019, 7. [CrossRef]

64. Martin, V.Y.; Greig, E.I. Young Adults' Motivations to Feed Wild Birds and Influences on Their Potential Participation in Citizen Science: An Exploratory Study. Biol. Conserv. 2019, 235, 295-307. [CrossRef]

65. Koss, R.S.; Kingsley, J.Y. Volunteer Health and Emotional Wellbeing in Marine Protected Areas. Ocean Coast. Manag. 2010, 53, 447-453. [CrossRef]

66. Kelly, R.; Fleming, A.; Pecl, G.T. Citizen Science and Social Licence: Improving Perceptions and Connecting Marine User Groups. Ocean Coast. Manag. 2019, 178, 104855. [CrossRef]

67. Williams, C.R.; Hawthorn-Jackson, D.; Orre-Gordon, S.; O'Sullivan, S.; O'Sullivan, S. Some Cautions in the Use of Citizen Science: A Case Study of Urban Insect Collection. Trans. R. Soc. S. Aust. 2017, 141, 57-69. [CrossRef]

68. Martin, V.Y.; Christidis, L.; Pecl, G.T. Public Interest in Marine Citizen Science: Is There Potential for Growth? BioScience 2016, 66, 683-692. [CrossRef] 
69. Cervinka, R.; Schwab, M.; Haluza, D. Investigating the Qualities of a Recreational Forest: Findings from the Cross-Sectional Hallerwald Case Study. Int. J. Environ. Res. Public Health 2020, 17, 1676. [CrossRef]

70. Dolrenry, S.; Hazzah, L.; Frank, L.G. Conservation and Monitoring of a Persecuted African Lion Population by Maasai Warriors. Conserv. Biol. 2016, 30,467-475. [CrossRef]

71. Schuttler, S.G.; Sears, R.S.; Orendain, I.; Khot, R.; Rubenstein, D.; Rubenstein, N.; Dunn, R.R.; Baird, E.; Kandros, K.; O'Brien, T.; et al. Citizen Science in Schools: Students Collect Valuable Mammal Data for Science, Conservation, and Community Engagement. BioScience 2019, 69, 69-79. [CrossRef]

72. Ganzevoort, W.; van den Born, R.J.G. Understanding Citizens' Action for Nature: The Profile, Motivations and Experiences of Dutch Nature Volunteers. J. Nat. Conserv. 2020, 55, 125824. [CrossRef]

73. García, M.B.; Silva, J.L.; Tejero, P.; Pardo, I.; Gómez, D. Tracking the Long-Term Dynamics of Plant Diversity in Northeast Spain with a Network of Volunteers and Rangers. Reg. Environ. Chang. 2019, 19, 391-401. [CrossRef]

74. Maund, P.R.; Irvine, K.N.; Lawson, B.; Steadman, J.; Risely, K.; Cunningham, A.A.; Davies, Z.G. What Motivates the Masses: Understanding Why People Contribute to Conservation Citizen Science Projects. Biol. Conserv. 2020, 246, 108587. [CrossRef] [PubMed]

75. Gharesifard, M.; Wehn, U. To Share or Not to Share: Drivers and Barriers for Sharing Data via Online Amateur Weather Networks. J. Hydrol. 2016, 535, 181-190. [CrossRef]

76. Ganzevoort, W.; van den Born, R.J.G.; Halffman, W.; Turnhout, S. Sharing Biodiversity Data: Citizen Scientists' Concerns and Motivations. Biodivers. Conserv. 2017, 26, 2821-2837. [CrossRef]

77. Musavi, M.; Friess, W.A.; James, C.; Isherwood, J.C. Changing the Face of STEM with Stormwater Research. Int. J. STEM Educ. 2018, 5. [CrossRef]

78. Carballo-Cárdenas, E.C.; Tobi, H. Citizen Science Regarding Invasive Lionfish in Dutch Caribbean MPAs: Drivers and Barriers to Participation. Ocean Coast. Manag. 2016, 133, 114-127. [CrossRef]

79. Alender, B. Understanding Volunteer Motivations to Participate in Citizen Science Projects: A Deeper Look at Water Quality Monitoring. J. Sci. Commun. 2016, 15. [CrossRef]

80. Koss, R.S.; Miller, K.; Wescott, G.; Bellgrove, A.; Boxshall, A.; McBurnie, J.; Bunce, A.; Gilmour, P.; Ierodiaconou, D. An Evaluation of Sea Search as a Citizen Science Programme in Marine Protected Areas. Pac. Conserv. Biol. 2009, 15, 116-127. [CrossRef]

81. Haywood, B.K.; Parrish, J.K.; Dolliver, J. Place-Based and Data-Rich Citizen Science as a Precursor for Conservation Action. Conserv. Biol. 2016, 30, 476-486. [CrossRef]

82. Tuckett, A.G.; Freeman, A.; Hetherington, S.; Gardiner, P.A.; King, A.C.; Scientists, B.B.C. Older Adults Using Our Voice Citizen Science to Create Change in Their Neighborhood Environment. Int. J. Environ. Res. Public Health 2018, 15, 2685. [CrossRef]

83. Zarybnicka, M.; Sklenicka, P.; Tryjanowski, P.; Zárybnická, M.; Sklenicka, P.; Tryjanowski, P. A Webcast of Bird Nesting as a State-of-the-Art Citizen Science. PLoS Biol. 2017, 15. [CrossRef]

84. Branchini, S.; Meschini, M.; Covi, C.; Piccinetti, C.; Zaccanti, F.; Goffredo, S. Participating in a Citizen Science Monitoring Program: Implications for Environmental Education. PLoS ONE 2015, 10. [CrossRef]

85. Martin, V.Y.; Christidis, L.; Lloyd, D.J.; Pecl, G.T. Understanding Drivers, Barriers and Information Sources for Public Participation in Marine Citizen Science. JCOM J. Sci. Commun. 2016, 15, A02. [CrossRef]

86. Zhang, S.; Shapiro, N.; Gehrke, G.; Castner, J.; Liu, Z.; Guo, B.; Prasad, R.; Zhang, J.; Haines, S.R.; Kormos, D.; et al. Smartphone App for Residential Testing of Formaldehyde (SmART-Form). Build. Environ. 2019, 148, 567-578. [CrossRef]

87. Moffat, A.J.; Doick, K.J. The Petersfield i-Tree Eco Survey-An Exercise in Community Ownership. Arboric. J. 2019, 41, 153-171. [CrossRef]

88. Edwards, R.; Kirn, S.; Hillman, T.; Kloetzer, L.; Mathieson, K.; McDonnell, D.; Phillips, T. Learning and developing science capital through citizen science. In Citizen Science: Innovation in Open Science, Society and Policy; Hecker, S., Haklay, M., Bowser, A., Makuch, Z., Vogel, J., Bonn, A., Eds.; UCL Press: London, UK, 2018; pp. 381-390. ISBN 978-1-78735-235-3.

89. Roche, J.; Bell, L.; Galvão, C.; Golumbic, Y.N.; Kloetzer, L.; Knoben, N.; Laakso, M.; Lorke, J.; Mannion, G.; Massetti, L.; et al. Citizen Science, Education, and Learning: Challenges and Opportunities. Front. Sociol. 2020, 5, 110. [CrossRef] [PubMed]

90. Thigpen, C.L.; Funk, C. Younger, More Educated U.S. Adults Are More Likely to Take Part in Citizen Science Research 2020. Available online: https: / / www.pewresearch.org/fact-tank/2020/06/25/younger-more-educated-u-s-adults-are-more-likelyto-take-part-in-citizen-science-research / (accessed on 25 March 2021).

91. Trumbull, D.J.; Bonney, R.; Bascom, D.; Cabral, A. Thinking Scientifically during Participation in a Citizen-Science Project. Sci. Educ. 2000, 84, 265-275. [CrossRef]

92. Haklay, M. Citizen Science and Policy: A European Perspective. Wash. DC Woodrow Wilson Int. Cent. Sch. 2015. Available online: https://www.wilsoncenter.org/sites/default/files/media/documents/publication/Citizen_Science_Policy_European_ Perspective_Haklay.pdf (accessed on 30 March 2021).

93. Cooper, C.B.; Dickinson, J.; Phillips, T.; Bonney, R. Citizen Science as a Tool for Conservation in Residential Ecosystems. Ecol. Soc. 2007, 12. [CrossRef]

94. Şekercioğlu, Ç.H. Promoting Community-Based Bird Monitoring in the Tropics: Conservation, Research, Environmental Education, Capacity-Building, and Local Incomes. Biol. Conserv. 2012, 151, 69-73. [CrossRef]

95. Stevens, M.; Vitos, M.; Altenbuchner, J.; Conquest, G.; Lewis, J.; Haklay, M. Taking Participatory Citizen Science to Extremes. IEEE Pervasive Comput. 2014, 13, 20-29. [CrossRef] 
96. Evans, C.; Abrams, E.; Reitsma, R.; Roux, K.; Salmonsen, L.; Marra, P.P. The Neighborhood Nestwatch Program: Participant Outcomes of a Citizen-Science Ecological Research Project. Conserv. Biol. 2005, 19, 589-594. [CrossRef]

97. Burgess, H.K.; DeBey, L.B.; Froehlich, H.E.; Schmidt, N.; Theobald, E.J.; Ettinger, A.K.; HilleRisLambers, J.; Tewksbury, J.; Parrish, J.K. The Science of Citizen Science: Exploring Barriers to Use as a Primary Research Tool. Biol. Conserv. 2017, 208, 113-120. [CrossRef]

98. Theobald, E.J.; Ettinger, A.K.; Burgess, H.K.; DeBey, L.B.; Schmidt, N.R.; Froehlich, H.E.; Wagner, C.; HilleRisLambers, J.; Tewksbury, J.; Harsch, M.A.; et al. Global Change and Local Solutions: Tapping the Unrealized Potential of Citizen Science for Biodiversity Research. Biol. Conserv. 2015, 181, 236-244. [CrossRef]

99. Burgos, A.; Páez, R.; Carmona, E.; Rivas, H. A Systems Approach to Modeling Community-Based Environmental Monitoring: A Case of Participatory Water Quality Monitoring in Rural Mexico. Environ. Monit. Assess. 2013, 185, 10297-10316. [CrossRef]

100. Wright, P.; Stevens, T. Designing a Long-Term Ecological Change Monitoring Program for BC Parks. J. Ecosyst. Manag. 2012, 13, $1-14$.

101. National Research Council. Ecological Indicators for the Nation; The National Academies Press: Washington, DC, USA, 2000; ISBN 978-0-309-06845-1.

102. González-García, F.J.; Blanco-López, Á.; España-Ramos, E.; Franco-Mariscal, A.-J. The Nature of Science and Citizenship: A Delphi Analysis. Res. Sci. Educ. 2019, 51,1-28. [CrossRef]

103. Queiruga-Dios, M.Á.; López-Iñesta, E.; Diez-Ojeda, M.; Sáiz-Manzanares, M.C.; Vázquez Dorrío, J.B. Citizen Science for Scientific Literacy and the Attainment of Sustainable Development Goals in Formal Education. Sustainability 2020, 12, 4283. [CrossRef]

104. Catlin-Groves, C.L. The Citizen Science Landscape: From Volunteers to Citizen Sensors and Beyond. Int. J. Zool. 2012. [CrossRef]

105. Hart, A.; Stafford, R.; Goodenough, A.; Morgan, S. The Role of Citizen Science and Volunteer Data Collection in Zoological Research. Int. J. Zool. 2012, 2012, 105345. [CrossRef]

106. Bloom, E.; Crowder, D. Promoting Data Collection in Pollinator Citizen Science Projects. Citiz. Sci. Theory Pract. 2020, 5, 3. [CrossRef]

107. Sauermann, H.; Franzoni, C. Crowd Science User Contribution Patterns and Their Implications. Proc. Natl. Acad. Sci. USA 2015, 112, 679-684. [CrossRef] [PubMed]

108. Toomey, A.H.; Domroese, M.C. Can Citizen Science Lead to Positive Conservation Attitudes and Behaviors? Hum. Ecol. Rev. 2013, $20,50-62$.

109. Newman, G.; Wiggins, A.; Crall, A.; Graham, E.; Newman, S.; Crowston, K. The Future of Citizen Science: Emerging Technologies and Shifting Paradigms. Front. Ecol. Environ. 2012, 10, 298-304. [CrossRef]

110. Rotman, D.; Preece, J.; Hammock, J.; Procita, K.; Hansen, D.; Parr, C.; Lewis, D.; Jacobs, D. Dynamic Changes in Motivation in Collaborative Citizen-Science Projects. In Proceedings of the ACM 2012 Conference on Computer Supported Cooperative Work, Seattle, WA, USA, 11-15 February 2012; pp. 217-226.

111. Danielsen, F.; Burgess, N.D.; Jensen, P.M.; Pirhofer-Walzl, K. Environmental Monitoring: The Scale and Speed of Implementation Varies According to the Degree of People's Involvement. J. Appl. Ecol. 2010, 47, 1166-1168. [CrossRef]

112. Aristeidou, M.; Scanlon, E.; Sharples, M. Weather-It: Evolution of an Online Community for Citizen Inquiry. In Proceedings of the 15th International Conference on Knowledge Technologies and Data-Driven Business, Graz, Austria, 21-22 October 2015.

113. Aristeidou, M.; Herodotou, C. Online Citizen Science: A Systematic Review of Effects on Learning and Scientific Literacy. Citiz. Sci. Theory Pract. 2020, 5. [CrossRef]

114. Herodotou, C.; Hlosta, M.; Boroowa, A.; Rienties, B.; Zdrahal, Z.; Mangafa, C. Empowering Online Teachers through Predictive Learning Analytics. Br. J. Educ. Technol. 2019, 50, 3064-3079. [CrossRef]

115. Palacin, V.; Gillbert, S.; Orchard, S.; Eaton, A.; Ferrario, M.A.; Happonen, A. Drivers of Participation in Digital Citizen Science: Case Studies on Järviwiki and Safecast. Citiz. Sci. Theory Pract. 2020, 5, 22. [CrossRef]

116. Brodie, S.; Litherland, L.; Stewart, J.; Schilling, H.T.; Pepperell, J.G.; Suthers, I.M. Citizen Science Records Describe the Distribution and Migratory Behaviour of a Piscivorous Predator, Pomatomus saltatrix. ICES J. Mar. Sci. 2018, 75, 1573-1582. [CrossRef]

117. Hobbs, S.J.; White, P.C.L. Achieving Positive Social Outcomes through Participatory Urban Wildlife Conservation Projects. Wildl. Res. 2015, 42, 607-617. [CrossRef]

118. Hobbs, S.J.; White, P.C.L. Motivations and Barriers in Relation to Community Participation in Biodiversity Recording. J. Nat. Conserv. 2012, 20, 364-373. [CrossRef]

119. O'Brien, J.M.; Thorne, J.H.; Rosenzweig, M.L.; Shapiro, A.M. Once-Yearly Sampling for the Detection of Trends in Biodiversity: The Case of Willow Slough, California. Biol. Conserv. 2011, 144, 2012-2019. [CrossRef]

120. Asingizwe, D.; Poortvliet, P.M.; van Vliet, A.J.H.; Koenraadt, C.J.M.; Ingabire, C.M.; Mutesa, L.; Leeuwis, C. What Do People Benefit from a Citizen Science Programme? Evidence from a Rwandan Citizen Science Programme on Malaria Control. Malar. J. 2020, 19, 283. [CrossRef]

121. Eisen, L.; Eisen, R.J. Benefits and Drawbacks of Citizen Science to Complement Traditional Data Gathering Approaches for Medically Important Hard Ticks (Acari: Ixodidae) in the United States. J. Med. Entomol. 2020. [CrossRef]

122. Walker, D.W.; Smigaj, M.; Tani, M. The Benefits and Negative Impacts of Citizen Science Applications to Water as Experienced by Participants and Communities. WIREs Water 2020, 8, e1488. [CrossRef]

123. McDougle, L.M.; Greenspan, I.; Handy, F. Generation Green: Understanding the Motivations and Mechanisms Influencing Young Adults' Environmental Volunteering. Int. J. Nonprofit Volunt. Sect. Mark. 2011, 16, 325-341. [CrossRef] 
124. Asah, S.T.; Blahna, D.J. Motivational Functionalism and Urban Conservation Stewardship: Implications for Volunteer Involvement. Conserv. Lett. 2012, 5, 470-477. [CrossRef]

125. Havens, K.; Vitt, P.; Masi, S. Citizen Science on a Local Scale: The Plants of Concern Program. Front. Ecol. Environ. 2012, 10, 321-323. [CrossRef]

126. Sullivan, B.L.; Wood, C.L.; Iliff, M.J.; Bonney, R.E.; Fink, D.; Kelling, S. EBird: A Citizen-Based Bird Observation Network in the Biological Sciences. Biol. Conserv. 2009, 142, 2282-2292. [CrossRef]

127. Barron, B.; Martin, C.K.; Mertl, V.; Yassine, M. Citizen Science: Connecting to Nature Through Networks. In Mass Collaboration and Education; Cress, U., Moskaliuk, J., Jeong, H., Eds.; Springer International Publishing: Cham, Switzerland, 2016 ; pp. $257-284$. ISBN 978-3-319-13536-6.

128. Lukyanenko, R.; Parsons, J.; Wiersma, Y.F. Emerging Problems of Data Quality in Citizen Science. Conserv. Biol. 2016, 30, 447-449. [CrossRef] [PubMed]

129. Mitchell, N.; Triska, M.; Liberatore, A.; Ashcroft, L.; Weatherill, R.; Longnecker, N. Benefits and Challenges of Incorporating Citizen Science into University Education. PLOS ONE 2017, 12, e0186285. [CrossRef] [PubMed]

130. Hecker, S.; Haklay, M.; Bowser, A.; Makuch, Z.; Vogel, J.; Bonn, A. Citizen Science: Innovation in Open Science, Society and Policy; UCL Press: London, UK, 2018.

131. Jacso, P. As We May Search-Comparison of Major Features of the Web of Science, Scopus, and Google Scholar Citation-Based and Citation-Enhanced Databases. Curr. Sci. 2005, 89, 1537-1547.

132. Meho, L.I.; Yang, K. A New Era in Citation and Bibliometric Analyses: Web of Science, Scopus, and Google Scholar. arXiv 2018, arXiv:cs/0612132. Available online: https://arxiv.org/abs/cs/0612132 (accessed on 23 April 2021).

133. Mongeon, P.; Paul-Hus, A. The Journal Coverage of Web of Science and Scopus: A Comparative Analysis. Scientometrics 2016, 106, 213-228. [CrossRef] 